\title{
$A M$
}

101

$5 E+$

n. . . +

\section{LAND SNAILS FROM HAWAII, CHRISTMAS ISLAND, AND SAMOA}

BY

HENRY A. PILSBRY, C. MONTAGUE COOKE, JR., AND MARIE C. NEAL

BERNICE P. BISHOP MUSEUM

BULLETIN 47

Honolul, Hawait

PUBLISHED BY THE MUSEUM 1928 


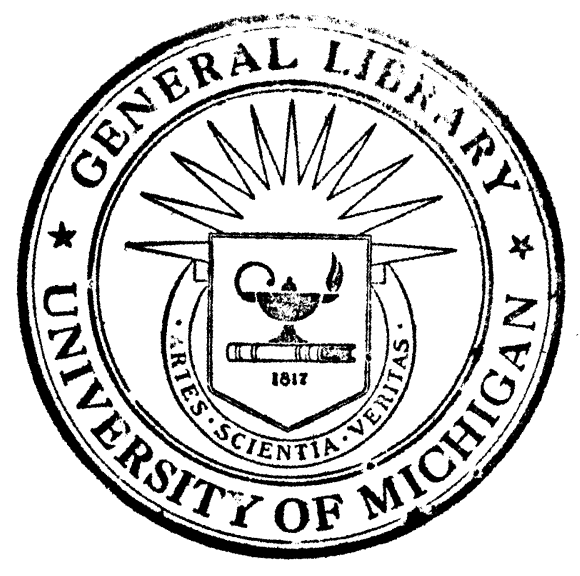




\section{.}




\title{
LAND SNAILS FROM HAWAII, CHRISTMAS ISLAND, AND SAMOA
}

\author{
BY \\ HENRY A. PILSBRY, C. MONTAGUE COOKE, JR., \\ AND MARIE C. NEAL
}

BerNice P. Bishop Museum

BULLETIN 47

Honol,ulu, Hawait

Published by the Museum

1928 
$A M$

101

.1354

nes. 4 ? 


\section{CONTENTS}

PAGE

Georissa, a land snail genus new to the Hawaiian islands, by Henry A. Pilsbry.......... 3

Food habits of Partula zebrina Gould, by C. Montague Cooke, Jr............................... 5

Introduction .......................................................................................................... 5

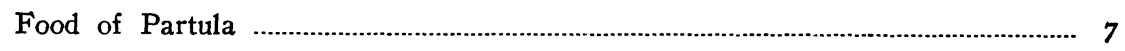

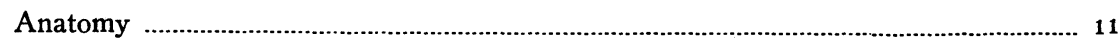

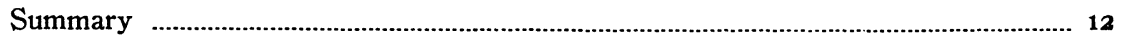

Three Endodonta from Oahu, by C. Montague Cooke, Jr............................................. 13

Introduction ....................................................................................................... 13

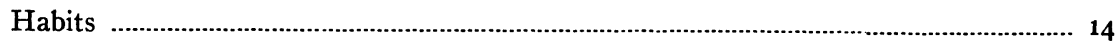

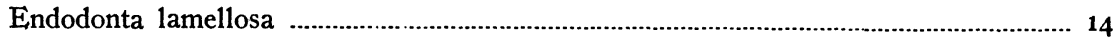

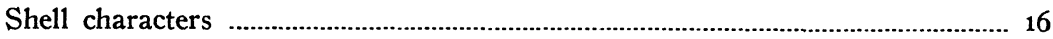

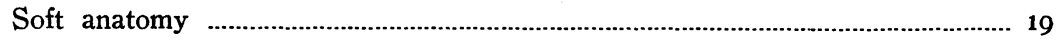

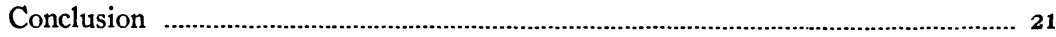

Endodonta marsupialis .............................................................................................. 21

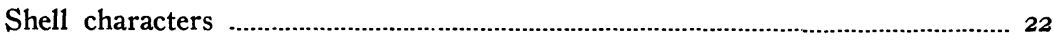

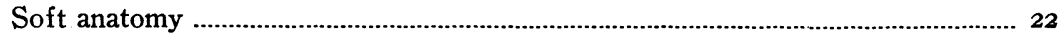

Conclusion .......................................................................................................... 24

Endodonta fricki .................................................................................................. 24

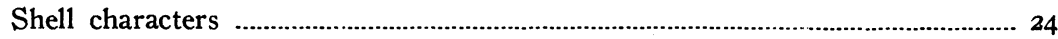

Soft anatomy ................................................................................................... 25

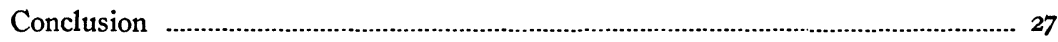

Bibliography .......................................................................................................................... 27

Distribution and anatomy of Pupoidopsis hawaiiensis, by C. Montague Cooke, Jr., and Marie C. Neal

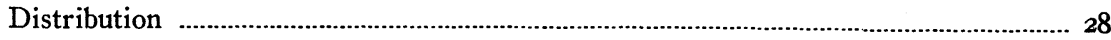

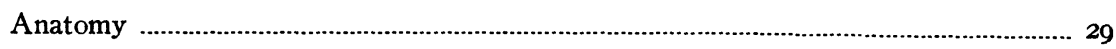

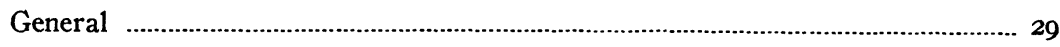

Jaw and teeth ……….................................................................................. 30

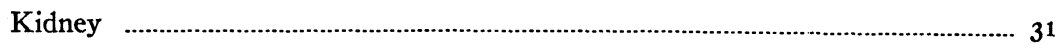

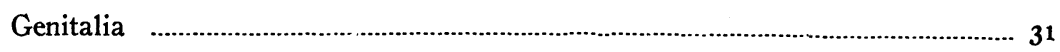

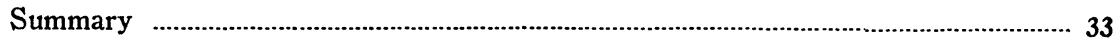

Anatomical studies of Achatinellidae, by Marie C. Neal................................................... 34

Comparison of representative species of the family................................................. 34

Development of genitalia in Achatinella viridans.......................................................... 44 
. 


\section{ILLUSTRATIONS}

FIGURE 1. Three new species of Georissa........................................................................ 4

2. Mouth parts of Partula zebrina and shells swallowed..................................... 11

3. Anatomy of Endodonta lamellosa........................................................................ 18

4. Free muscles and teeth of Endodonta lamellosa................................................. 19

5. Reproductive organs of Endodonta lamellosa...................................................... 20

6. Reproductive organs and teeth of Endodonta marsupialis.................................. 23

7. Reproductive organs and tooth of Endodonta fricki......................................... 26

8. Expanded animal, pallial organs, and alimentary tract of Pupoidopsis hawaiiensis .............................................................................................. 28

9. Reproductive organs of Pupoidopsis hawaiiensis............................................... 30

10. Reproductive organs, teeth, jaw, and position of tentacles of Pupoidopsis

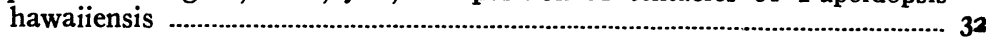

11. Pallial organs and alimentary tract of Partulina redfieldii, $P$. horneri, $P$. virgulata, and $P$. mauiensis.................................................................... 35

12. Pallial organs and alimentary tract of Newcombia canaliculata and Achatinella lehuiensis var. meineckei............................................................... 36

13. Genitalia of Partulina redfieldii.................................................................... 36

14. Genitalia of Achatinella lehuiensis var. meineckei, Partulina virgulata, and $P$. rufa

15. Genitalia of Partulina mauiensis, P. horneri, P. dubia, and Newcombia cumingi

16. Nerve collar of Partulina redfieldii.................................................................. 42

17. Genitalia of Achatinella viridans............................................................... 44

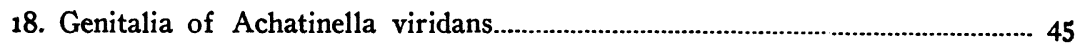

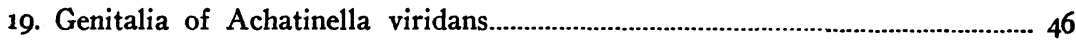

20. Genitalia of Achatinella viridans.................................................................. 47

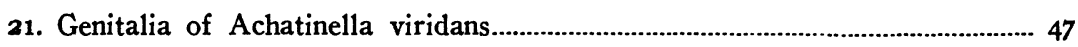

22. Genitalia of Achatinella viridans................................................................... 48 



\title{
Land Snails from Hawaii, Christmas Island, and Samoa
}

\author{
By \\ Henry A. Pilsbry, C. Montague Cooke, Jr., and Marie C. Neal
}

\begin{abstract}
GEORISSA, A LAND SNAIL GENUS NEW TO THE HAWAIIAN ISL,ANDS
\end{abstract}

BY HENRY A. PILSBRY

In the course of a trip to Kauai, Marie C. Neal, Assistant Malacologist, Bernice P. Bishop Museum, had the good fortune to collect specimens of three species of Georissa, forming the subject of this paper.

The special interest of this discovery lies in the fact that it adds a genus and a family new to the Hawaiian fauna. It is, moreover, a group of purely terrestrial station, not a seashore or atoll dweller such as Truncatella; therefore the less likely to be transported by natural rafts or other means of oversea drift. The nearest known neighbors of these Kauaian Georissa are in Guam and in the Society Islands. The species here described appear to be more closely related to those of the Society Islands than to species of Guam. On the western borders of the Pacific, the genus Georissa. is known from Japan, China, the Philippines, and southward to tropical Queensland. Eastward it is spread through the Cook and Society islands to the Marquesas.

All of the species were taken on a ridge between Hanalei and Wailua, Kauai, on the Pole Line Trail between Kualapa and the summit camp, elevation about 2,000 feet, in moss collected on fallen logs. The moss was subsequently dried, and the shells were found in the finest siftings, the only other shells occurring with them being young specimens of Tornatellina and Leptachatina and a single specimen of an undescribed species of Punctum.

Georissa cookei, new species (figure $1, \dot{a}$ ).

The shell is conic, orange-cinnamon colored, composed of $3^{\mathrm{T} / 2}$ strongly convex whorls. The first whorl appears to be smooth or very minutely punctate; the last two whorls are encircled with low spiral cords about as wide as their intervals. At 
the beginning of the last whorl are about 5 or 6 cords between lip and suture; on the base the spirals are smaller and weaker. The oblique aperture is somewhat wider than semicircular. Columellar margin straight, heavily calloused.

Length $1 \mathrm{~mm}$., diam. $0.8 \mathrm{~mm}$., height of aperture, $0.5 \mathrm{~mm}$.
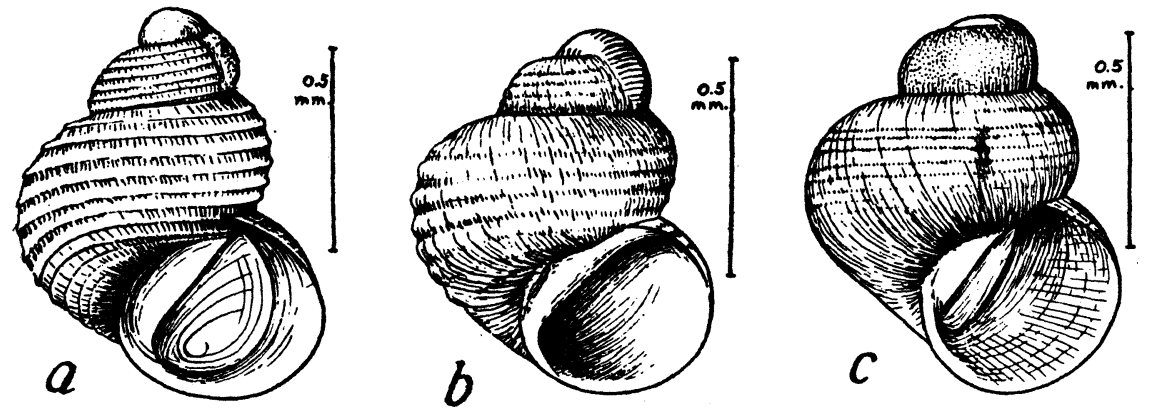

FIGURE 1.-Georissa: a, Georissa cookei, new species; $b$, Georissa neali, new species; c, Georissa kauaiensis, new species.

Type, 131432, Academy of Natural Sciences of Philadelphia; paratype, 59188, Bishop Museum.

Georissa neali, new species (figure $1, b$ ).

The shell is decidedly shorter than $G$. cookei, of $21 / 2$ strongly convex whorls. The embryonic shell is inflated, hemispherical, deeply and closely striate across (Trivia-like, as seen from above). Subsequent whorls have a few low, wide, somewhat uneven spiral cords. The aperture is strongly oblique, semicircular, the straight columellar margin heavily calloused. Color white, but probably bleached.

Length $0.85 \mathrm{~mm}$., diam. $0.75 \mathrm{~mm}$.

Type, 131433, Academy of Natural Sciences of Philadelphia; paratype, 59189, Bishop Museum.

Georissa kauaiensis, new species (figure 1, c).

The shell is light pinkish cinnamon, somewhat more globose than G. neali, with the first whorl of more regular shape, not striate, but showing a faint, close microscopic punctation; $2 \frac{1}{2}$ whorls, the last having faint traces of spiral sculpture.

Length $0.9 \mathrm{~mm}$., diam. $0.8 \mathrm{~mm}$.

Type, 131431, Academy of Natural Sciences of Philadelphia; paratype, 59187, Bishop Museum.

The type of this species is evidently not adult, but it differs from its fellows so much in sculpture that it must represent another species. The embryonic whorl appears to be larger than in G. cookei, and subsequent whorls are far less strongly sculptured.

Very few specimens of these tiny shells have been examined, and their limits of variation are unknown. They are the smallest species yet known in the genus. 


\section{FOOD HABITS OF PARTULA ZEBRINA GOULD ${ }^{1}$}

BY C. MONTAGUE COOKE, JR.

\section{INTRODUCTION}

The family Partulidae contains but the single genus Partula. This family is confined to high islands of the Pacific and has no near relatives on any of the continents bordering this ocean. The eastern limits are Rapa and the Marquesas islands, the western the Pelew, Talauer, and Admiralty islands. It does not occur in the Hawaiian islands to the north, and its southernmost representative is on the island of Rapa.

Most of the literature on the genus Partula is taxonomic. While little is devoted to distribution, still less has been written on the habits of the snails. Crampton is the only writer who has closely studied the habits of the genus. $^{2}$ Other than that certain species are arboreal or terrestrial I can find nothing else that has been published. Crampton found that

... the greater number of species in Tahiti, in the Society Islands, and elsewhere, whose representatives are arboreal during the day time ... [remain] sealed up on the under sides of leaves less than 10 to 15 feet from the ground; at night, however, they resume activity and crawl to the earth to feed upon decaying vegetation. ... Under normal conditions ... Partulae resume activity at night and become quiet in bright light, in practically 95 per cent of the cases as observed in the laboratory, and in experiments in the field where snails were placed on suitable plants at the coast for determination of this point. But if the atmosphere is very dry, they are apt to remain sealed up all night, while, on the other hand, if the sky becomes clouded and the light is reduced, they will crawl about even in the day time. When rain falls and humidity increases greatly, they move about with celerity, crawl to the ground, and resume feeding.

As far as I can learn the only observations in regard to their food have been made by the same author. To quote again:

The character of the food of Partulae is a matter of considerable interest, in view of the theoretical possibility that differences in the vegetation of separated valleys might be adduced to account for the diverse characteristics of the snails in such different localities. When the facts are examined, however, this possibility is ruled out. Confining our attention to the low arboreal species, and disregarding those of the ground and of the highest tree-tops, we have several independent series of data that justify the statement given. In the first place, it is clear that the snails do not feed on the living tissue of the plants upon which they are found, because the organisms may be present in numbers on a perfect unmutilated leaf, and because no leaves occur that display alterations saving such as are made by insect larvae. Secondly, the animals go to the ground to feed, as described in the foregoing paragraphs. Thirdly, the stomach-contents of active and newly killed snails comprise no fresh vegetable material,

1 Read at the second annual meeting of the Hawaiian Academy of Science, May 7, 1927.

2 Read at the second annual meeting of the Hawaibution, and evolution of the genus Partula: Carnegie Inst. Washington, Pub. 228, pp. 24-26, 1916. 
but only the rasped fragments of decaying woody and fleshy plant tissues. Again, animals that were feeding under observation in nature avoided the living parts of plants and restricted themselves to decaying leaves and wood. Finally, the specimens that were brought back to the laboratory ate moist dead leaves with avidity; only when very hungry did they eat the whiter and firmer portions of lettuce and cabbage leaves. In transporting them from the field, they consumed great quantities of wet paper, which to all intents and purposes, is wood pulp. Dall has suggested that in the case of Achatinellidae decaying vegetation is eaten for the sake of the fungi that grow in and upon it. Whether or not the same is true for Partulae, the fact remains that the nurse-plants upon which Partulae are found during the day do not seem to have any effect upon the specific or varietal characters displayed by these animals. We would scarcely expect that this would be so, when representatives of three distinct species may be sealed up on a single leaf of caladium, plantain, or Dracaena.

Last year in company with Mr. A. F. Judd and Mr. Theodore T. Dranga, I spent six weeks in American Samoa. On the Island of Tutuila three species of Partula were taken. These three species were found associated in different proportions, in some localities, but in many localities only the most common species, Partula zebrina Gould, was found. The habitats of two of the species, Partula conica Gould, and Partula abbreviata Mousson, were also slightly different from those of $P$. zebrina. The first two species were usually taken on the trunks and branches of trees and shrubs but sometimes on the leaves, while $P$. zebrina was taken under almost all conditions, usually on the leaves of shrubs and trees, sometimes on trunks and branches of trees. A considerable per cent were also found on and under dead leaves on the ground and a very few on stones. No observations were made by any of us as to whether they were nocturnal in their habits, but it was very noticeable that a large number of specimens were active and crawling during rain and shortly after.

Nearly all our material was expanded by drowning and brought back to Honolulu in alcohol. During the early stages of the process of extracting animals from shells, Miss Neal found a specimen of Aphanoconia in the body of a young specimen of $P$. zebrina, which led to a tentative examination of every specimen of Partula that was cleaned in the laboratory. All animals in the stomachs of which shells were found were isolated for further study, and some of them served as the material on which this paper is based. I have used only a portion of the data collected and have examined critically the stomachs of about 200 specimens.

The catalog numbers of the specimens referred to in this paper are as follows: Amouli, 84173-84185, 84228, 84234, and 84238-84243; Pago Pago, $83779-83789$ and $83821-83831$; Fagasa (arboreal), 83919-83933 and 8393783942; Fagasa (terrestrial), 83970-83975; Mount Tau, 84457; Logotala, 84783 . 


\section{FOOD OF PARTULA}

Judging from the type of the teeth of Partula, the genus is herbivorous. As shown by Crampton, the stomach contents of Tahitian species is made up of decayed vegetable matter, which was found also in some of the Samoan snails. To determine this point, the stomachs of 50 P. zebrina were examined. Of these, nine were empty or nearly so, and one or two were found to contain matter that could be classed strictly as decayed vegetable matter, as it was very black. In most specimens the vegetable material consists of very fine brownish particles, which appeared to be made up of rather newly dead vegetable matter. In addition to this material, 21 specimens had the stomachs crowded with or partly full of a compact white mass. Dr. Brown has made a careful microscopic study of this material and has come to the conclusion that it is the undigested remains of vegetable matter. In the stomach of one specimen, in addition to the white mass already mentioned, Dr. Brown was able to recognize partly digested, newly dead leaf cells and fibers, diatoms, Protococcus, fern sori, bacteria, pollen grains, etc. Of the 50 specimens examined, only three contained the remains of shell animals. As the shells had been completely dissolved and the animals crowded in with vegetable matter, none of the genera was recognizable.

Of the three species of Partula occurring on the Island of Tutuila, only $P$. zebrina was found to have acquired the habit of swallowing other land shells. Of the many hundreds of specimens of $P$. conica and $P$. abbreviata that were tentatively exanined, not a single stomach was found to contain a shell. This is probably due to the relatively thicker shell of $P$. zebrina, and, as I will try to show later, shells are swallowed merely to procure lime for the formation of new shell material.

The frequency of this habit is illustrated by Table 1, for which I have selected specimens from five somewhat separated colonies.

TABLE 1. FREQUENCY OF THE, SHELL-SWALLOWING HABIT IN PARTULA ZEBRINA

\begin{tabular}{|c|c|c|c|c|c|c|c|c|}
\hline \multirow[b]{2}{*}{ Colony } & \multicolumn{4}{|c|}{$A D U L T$} & \multicolumn{4}{|c|}{ YOU N G } \\
\hline & 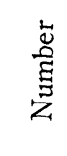 & 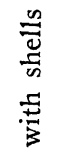 & 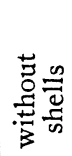 & 岕莕 & 岕 & 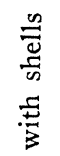 & 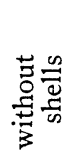 & 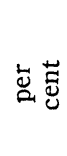 \\
\hline Amouli & 138 & 22 & 116 & 16 & 27 & 14 & 13 & 52 \\
\hline Pago Pago ....................... & 72 & 22 & 50 & 30 & 52 & 30 & 22 & 58 \\
\hline Fagasa (arb.) & 120 & 21 & 99 & 17 & 43 & 17 & 26 & 40 \\
\hline Fagasa (ter.) & 6 & 2 & 4 & 33 & 9 & 5 & 4 & 55 \\
\hline Mount Tau & 50 & 13 & 37 & 26 & 20 & 11 & 9 & 55 \\
\hline Logotala & 137 & 9 & 128 & 6 & 18 & 9 & 9 & 50 \\
\hline Totals & 523 & 89 & 434 & 17 & 169 & 86 & 83 & 51 \\
\hline
\end{tabular}


The table is based on nearly 700 specimens. It shows that the occurrence of this habit in juveniles is almost exactly three times as frequent as in adults. This is undoubtedly due to the great need for lime in young growing shells.

The species of shells and the number of individuals swallowed was tabulated from 43 specimens of adult and 40 specimens of juvenile stomachs. A summary of the results is seen in Tables 2 and 3.

TABLE 2. NUMBER OF SHELLS SWALLOWED BY PARTULA ZEBRINA.

\begin{tabular}{|c|c|c|c|c|c|c|c|c|c|c|c|c|c|c|c|c|}
\hline \multirow[b]{2}{*}{ Colony } & \multicolumn{8}{|c|}{$A D U L T$} & \multicolumn{8}{|c|}{ YOUNG } \\
\hline & $\begin{array}{l}\text { Number } \\
\text { in } \\
\text { stomach }\end{array}$ & 1 & 2 & 3 & 4 & 5 & 6 & 7 & $\begin{array}{l}\text { Number } \\
\text { in } \\
\text { stomach }\end{array}$ & 1 & 2 & 3 & 4 & 5 & 6 & 7 \\
\hline $\begin{array}{l}\text { Amouli .......... } \\
\text { Pago Pago...... } \\
\text { Fagasa .......... } \\
\text { Mount Tau .... }\end{array}$ & $\begin{array}{l}10 \\
10 \\
10 \\
13\end{array}$ & $\begin{array}{l}3 \\
4 \\
7 \\
9\end{array}$ & $\begin{array}{l}5 \\
6 \\
3 \\
3\end{array}$ & 2 & & & & 1 & $\begin{array}{l}16 \\
12 \\
12\end{array}$ & $\begin{array}{l}4 \\
8 \\
7\end{array}$ & $\begin{array}{l}3 \\
2 \\
4\end{array}$ & $\begin{array}{l}6 \\
1\end{array}$ & $\begin{array}{l}1 \\
2\end{array}$ & 1 & & 1 \\
\hline Totals ................ & 43 & 23 & 17 & 2 & & & & 1 & 40 & 19 & 9 & 7 & 3 & 1 & & 1 \\
\hline
\end{tabular}

From Table 2 it is seen that 43 adult specimens had swallowed 70 shells with an average of nearly 1.7 shells to each individual, while 40 juveniles had swallowed 82 shells with an average of just over two shells for a meal. Of the 83 specimens, 42 had swallowed 1 shell, 26 had swallowed 2, 9 had swallowed 3, 3 had swallowed 4, 1 had swallowed 5, and 2 had swallowed 7 specimens.

As shown in Table 3 , of the 152 shells that had served as meals, 140 were terrestrial in habit, only 12 arboreal. Only 5 of the 13 terrestrial genera found in Tutuila seemed to have been swallowed by $P$. zebrina. Whether the other terrestrial genera (Trochonanina, Patula, Succinea, Gastrocopta, Gulella, Tornatellina, Ostodes, Assiminea) are distasteful I do not know; but two at least (Ostodes and Assiminea) would rank among the five most abundant genera in point of individual numbers. No specimen of the very abundant arboreal genera Trochonanina nor Trochomorpha nor Partula was found in any of the stomachs examined. It is probable that some of these species, especially the arboreal, are too active to be caught.

Most of the shells which had been swallowed were alive when they reached the stomachs of their captors. This was clearly shown by the large number of specimens with the animal fully or partly expanded. Several animals were as fully expanded as in freshly drowned specimens. None of these shells had been attacked by the digestive fluid. 
TABLE 3. GENERA OF SHELLS SWALLOWED BY PARTULA ZERRINA.

\begin{tabular}{|c|c|c|c|c|c|c|c|c|c|c|}
\hline \multicolumn{11}{|c|}{$A D U L T$} \\
\hline Colony & 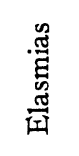 & 苞 & 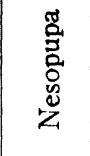 & 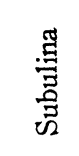 & జूँ & 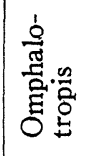 & 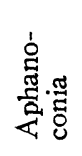 & ت्ञّ & 离 & 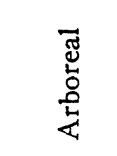 \\
\hline $\begin{array}{l}\text { Amouli } \\
\text { Pago Pago } \\
\text { Fagasa } \\
\text { Mount Tau }\end{array}$ & 1 & $\begin{array}{l}2 \\
2 \\
3\end{array}$ & 2 & $\begin{array}{r}5 \\
2 \\
10 \\
3\end{array}$ & $\begin{array}{l}3 \\
3 \\
3\end{array}$ & $\begin{array}{l}6 \\
2\end{array}$ & $\begin{array}{l}5 \\
8 \\
1 \\
9\end{array}$ & $\begin{array}{l}19 \\
16 \\
13 \\
22\end{array}$ & $\begin{array}{l}19 \\
13 \\
11 \\
19\end{array}$ & $\begin{array}{l}3 \\
2 \\
3\end{array}$ \\
\hline Total & 1 & 7 & 2 & 20 & 9 & 8 & 23 & 70 & 62 & $8(11 \%)$ \\
\hline \multicolumn{11}{|c|}{ YOUNG } \\
\hline $\begin{array}{l}\text { Amouli } \\
\text { Pago Pago } \\
\text { Fagasa }\end{array}$ & 1 & 3 & & $\begin{array}{r}24 \\
8 \\
11\end{array}$ & $\begin{array}{l}2 \\
3\end{array}$ & $\begin{array}{r}13 \\
3\end{array}$ & $\begin{array}{l}5 \\
6 \\
3\end{array}$ & $\begin{array}{l}44 \\
20 \\
18 \\
\end{array}$ & $\begin{array}{l}44 \\
17 \\
17 \\
\end{array}$ & $\begin{array}{l}3 \\
1\end{array}$ \\
\hline & 1 & 3 & & 43 & 5 & 16 & 14 & 82 & 78 & $\overline{4(5 \%)}$ \\
\hline Total & 2 & 19 & 2 & $\overline{63}$ & 14 & 24 & 37 & 152 & 140 & 12 \\
\hline
\end{tabular}

Of the 41 specimens that had swallowed more than one specimen, 17 had shown some discrimination by confining themselves to a single genus, 22 had representatives of two genera, and only 2 had specimens of three genera in their stomachs. (See Table 4.)

TABLE 4. NUMBER OF GENERA IN STOMACHS OF PARTULA ZEBRINA

\begin{tabular}{|c|c|c|c|}
\hline \multicolumn{4}{|c|}{ ADULT } \\
\hline $\begin{array}{c}\text { Number of specimens } \\
\text { in stomach }\end{array}$ & $\begin{array}{l}\text { One } \\
\text { genus }\end{array}$ & $\begin{array}{l}\text { Two } \\
\text { genera }\end{array}$ & $\begin{array}{l}\text { Three } \\
\text { genera }\end{array}$ \\
\hline $\begin{array}{l}2 \\
3 \\
7\end{array}$ & $\begin{array}{l}8 \\
1\end{array}$ & $\begin{array}{l}9 \\
1 \\
1\end{array}$ & \\
\hline & 9 & 11 & 0 \\
\hline \multicolumn{4}{|c|}{ YOUNG } \\
\hline $\begin{array}{l}2 \\
3 \\
4 \\
5 \\
7\end{array}$ & $\begin{array}{l}3 \\
5\end{array}$ & $\begin{array}{l}6 \\
2 \\
2 \\
1\end{array}$ & $\begin{array}{l}1 \\
1\end{array}$ \\
\hline & 8 & 11 & 2 \\
\hline
\end{tabular}


Slightly more than half the specimens (77) that had been swallowed belong to the genera Subulina and Opeas. Although not indigenous to the Samoan fauna, these genera would easily rank in abundance of individuals among the first five. I consider that the high per cent of representation is due to their abundance rather than that $P$. zebrina shows preference for these genera.

Only four shells were found that had died before being swallowed. I do not think that this shows conclusively that live shells are preferred, but that due to conditions under which $P$. zebrina were feeding, namely, on dead leaves, dead shells would scarcely occur.

All the snails that have conic or oblong shells, in which the shell is somewhat longer than broad, were swallowed base first. I consider that this is due to their habits of feeding. From the fact that feeding snails have the mouth in contact with the surface on which they are crawling they would naturally come in contact with the base of their prey rather than with the apical portion.

Only a very few shells that had been swallowed were in perfect condition when examined. A great majority had portions of the shell more or less dissolved by some secretion. That the shells were swallowed primarily for their lime was shown by the very slight effect that the secretions in the stomach had upon the animals. About one-tenth of the swallowed shells had the animal partly or fully expanded, showing that the digestive ferments were nonirritating or the animals would have contracted into their shells. A considerable number of individuals were noted in which the delicate surface color markings of the animals were intact, though quite large portions of the shell had been dissolved. All the lime of some shells had been dissolved, with the animal and organic matter of the shell in such perfect condition that not only the genus but the species of the individual could be recognized.

That these secretions did not penetrate into the animals was seen in three or four specimens of Subulina or Opeas that were pregnant with eggs. In these, although the shells were considerably dissolved, the egg shells were not dissolved or only dissolved in the portion that was in proximity with the outer wall of the animal. One interesting specimen of Subulina was found in which two egg shells had been dissolved, but the very delicate embryonic shells embedded in the albumen of the eggs were not attacked.

Most of the stomachs that contained shells contained little or no vegetable matter; but a few were crowded with vegetable material and had shells in addition. 


\section{ANATOMY}

The mouth of an average specimen of Partula zebrina measures externally slightly less than $2 \mathrm{~mm}$. in its longest diameter. Back of the mouth is the buccal mass, which consists of a rather solid series of muscles for working the jaw and radula. Attached to the upper portion of the buccal mass is the esophagus, a long, rather slender tube leading to the crop or stomach. The esophagus is from $.75 \mathrm{~mm}$. to $1.25 \mathrm{~mm}$. in diameter. Shells have been taken from the stomach of a $P$. zebrina measuring $7 \mathrm{~mm}$. in diameter. That individuals swallowing shells must be put to a great deal of inconvenience is to be assumed, since the diameter of a shell may be from seven to ten times that of the esophagus. (See fig. 2, $a, b, c$, and $e$.)
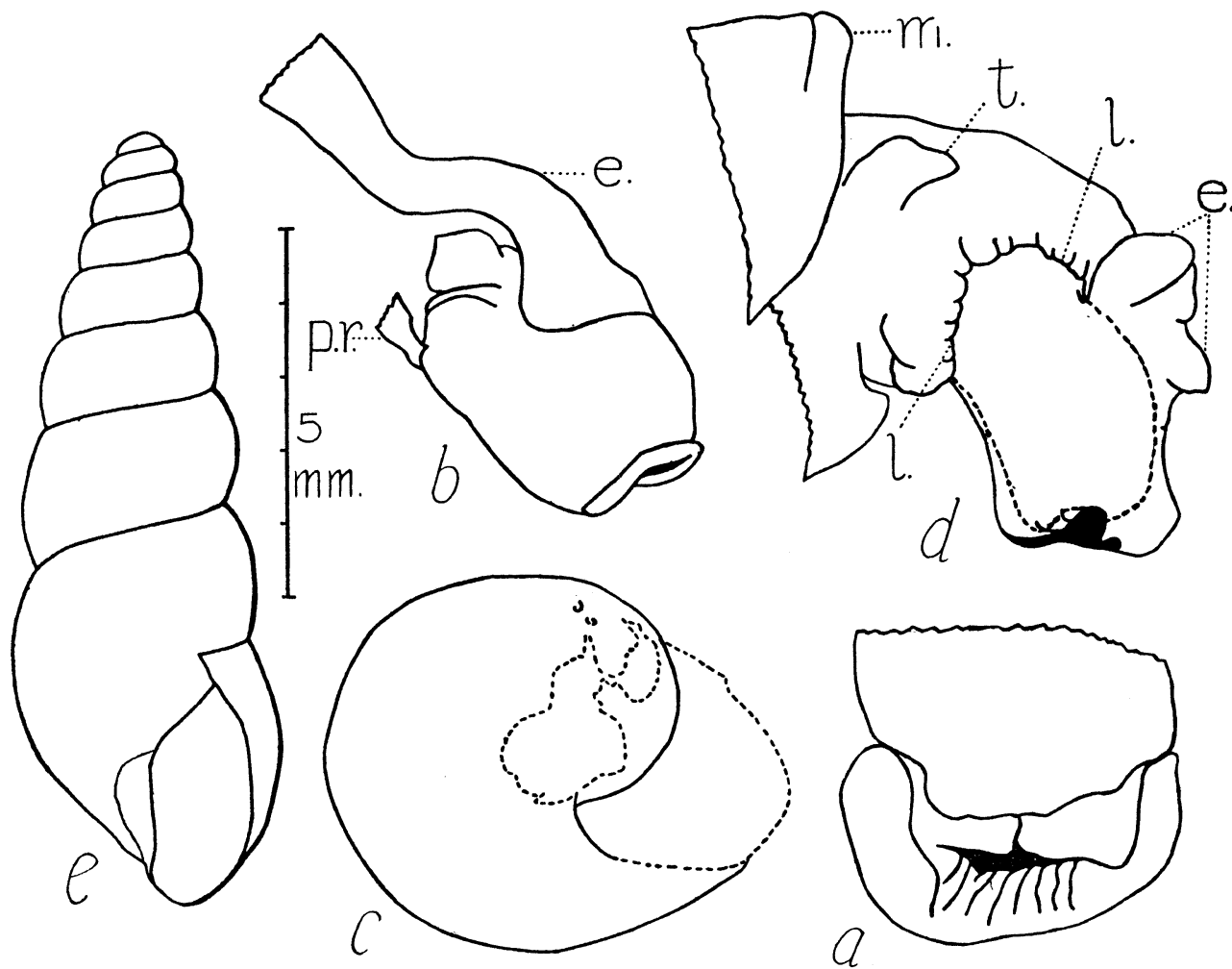

FIGURE 2.-Partula zebrina, showing shells swallowed and mouth: a, Partula zebrina Gould, lower surface of the animal, showing mouth and fore end of foot; $b$, buccal mass of the same individual dissected out, showing esophagus, e. $=$ esophagus, p. r. = pharyngeal retractor; $c$, specimen of Aphanoconia fulgora Gould taken from the stomach of the same individual, dashes represent where the shell was eroded; $d$, another individual with the buccal mass extruded, e. $=$ esophagus, $1 .=1 \mathrm{ip}, \mathrm{m} .=$ mantle, $\mathrm{t}$. = tentacle, dashes represent the position of the buccal mass; e, specimen of Opeas taken from the stomach of a third individual.

(All figures drawn with the same magnification.) 
The mechanics of this performance must be intensely interesting. Fortunately a few specimens were found that offer a clue as to how this is accomplished. In these specimens the whole buccal mass and part of the esophagus was extruded beyond the lips. (See fig. 2, d.) Probably a lime-hungry $P$. zebrina coming in contact with its prey extrudes the mouth, which by pressure enlarges and surrounds the victim. Then by contraction of the mouth the shell is forced into the esophagus and thence into the stomach.

One difficulty has to be met before this is accomplished for the first time. The central nervous system of a snail is made up of a number of ganglia united by commissures to form a ring, through which the esophagus passes. In $P$. conica and abbreviata these ganglia are united by relatively short and thick commissures so that the ring fits rather closely to the esophagus and is only slightly larger in diameter. In some individuals of $P$. zebrina that had swallowed shells, this ring was enlarged to approximately three times the diameter of that of a species of Partula with normal habits, although the ring was not as large as the undissolved shells that had passed through it a short time before. The ganglia of $P$. zebrina are united by relatively much thinner commissures than those in species of Partula with normal habits. In one specimen of $P$. zebrina that contained only vegetable matter in the stomach, the ganglion ring was more contracted but still fitted loosely around the esophagus. Undoubtedly this ganglion ring is stretched to a large extent when an individual swallows a relatively large snail, afterwards contracting somewhat, but not regaining the size of a normal ganglion ring of the genus. Evidently, therefore, not only the mouth and esophagus and other alimentary parts of the snail are greatly stretched, but also the part that functions as the brain of the animal is considerably altered.

\section{SUMMARY}

The species Partula zebrina, an herbivorous snail, has acquired the habit of swallowing other species of snails. From the relative size of the victims this must be accomplished with much inconvenience, if not pain, as not only the alimentary organs but even the central nervous system are stretched to many times their normal size. Since the secretions in the stomach apparently attack only the calcareous material, leaving the animal matter practically untouched, at least until some time after the shell is completely dissolved, it is presumed that these shells are swallowed solely to procure lime. This can be explained also by the relatively larger proportion of young specimens showing this habit than adults, as the growing shell needs a larger amount of lime. 


\section{THREE ENDODON'TA FROM OAHU ${ }^{3}$}

BY C. MON'TAGUE COOKE, JR.

\section{INTRODUCTION}

This paper is an attempt to identify and define the three species of Endodonta (sensu stricto) that have been described from Oahu: E.lamellosa Férussac, E. marsupialis Pilsbry and Vanatta, E. fricki Pfeiffer. Among collections their exact determination is in doubt, and in attempts to clarify the situation different authors have added somewhat to the confusion. The exuct determination of Endodonta lamellosa I feel sure of, as the figure given by Férussac (2 ${ }^{4}$ represents in its main characters shells from the top of Konahuanui. Though the original specimens probably did not come from this restricted colony, doubtless they were obtained at no very great distance and at a considerably lower elevation.

Two paratype specimens of Endodonta marsupialis were kindly deposited in the Bernice P. Bishop Museum by Dr. Pilsbry, and I collected additional typical material on the Pauoa slope of Mount Tantalus. Undoubtedly Dr. Pilsbry's original material was collected in the immediate vicinity, as that region is easily accessible to Honolulu and the additional material agrees closely with the paratypes.

Of Endodonta fricki I feel fairly certain. In 1905 I compared three specimens (Catalog No. 14291) with the supposed types in the British Museum and identified them as this species. Unfortunately the comparison was not as critical as I could wish; According to my notes the only marked difference is a proportionately higher spire in the original specimens. When preparing this paper I noticed that Pfeiffer (7) mentions one important character not found in any Oahuan species of the typical section, namely, a margined suture. This character, if distinct, belongs to a quite different group of species, which cannot be included in Pfeiffer's diagnoses and certainly does not approach his figure, which is of a typically Waianae species. The number of whorls given by Pfeiffer does not agree with any of the Waianae forms known to me.

The locality from which Pfeiffer's type specimens came can be determined only on comparison with a number of carefully collected specimens representing the numerous geographical races.

${ }^{3}$ This paper was submitted to Dr. Henry A. Pilsbry for suggestions. In a letter dated November 3,1927 , he says: "I have reviewed the subject in the light of your researches and agree with your results. ....At the time I wrote, only very few people appreciated how local those Hawaiian species are; certainly I did not. I have gone over our shells and believe your conclusions as to E. fricki are correct."

The numbers in parentheses refer to Bibliography, page 27. 


\section{HABITS}

All the Hawaiian species of Endodonta (sensu stricto) are terrestrial and have strictly sedentary habits. Colonies of some of the species found only a few hundred yards apart and separated by some natural barrier, such as a barren ridge or absence of forest growth, are easily recognized as distinct geographical races. Some of these races are more circumscribed in their known habitats than are the well-known geographical races of Achatinella. A few species are more widely distributed and do not appear to have given rise to distinct races.

In population and numbers, the two mountain ranges of Oahu offer a decided contrast. On the longer Koolau Range living specimens have been taken, as far as I know, in only five or six localities; though at one time, when the island was more heavily and evenly forested, as evidenced by fossil material, this genus was widely and abundantly distributed over the whole lower region, down to and including parts of the coastal plain. On the other hand, the shorter and drier Waianae Mountains, only a few miles distant, have a very abundant and varied Endodonta faunula.

In the Koolau Range four of the five colonies have been located on the higher, very damp mountain peaks at altitudes of 2,500 to 3,000 feet. The only exception is a colony on the side of Mount Tantalus at an elevation of about 1,700 feet. All the specimens from the Koolau Range were taken on dead leaves and twigs. In the Waianae Mountains the representatives of this genus do not seem to be so particular as to habitat. Almost any suitable locality, as a mountain ravine more or less covered with forest growth and fairly damp, and some unsuitable localities, dry and exposed, may each be inhabited by a more or less well-populated colony of one species. However, in some localities that are apparently suitable not a shell can be found. In many colonies that occupy a small area the specimens are abundant and by their great similarity give evidence of descent from a single individual or at least a very few individuals and of close in-breeding. As far as I am aware, no colony of Endodonta has been found in a talus slope in the Koolau Range. Several isolated colonies have been found living in talus slopes of the Waianae Mountains, some of them in dry and exposed situations.

\section{ENDODONTA LAMELLOSA}

\section{Endodonta lamellosa (Férussac)}

Helix (Helicodonta) lamellosa Férussac: Prodrome, p. 35, no. 110, 1822 (nude name) ; Hist. Nat. Moll., pl. 51A, fig. 3; Voy. Freycinet, Zool., p. 469, 1824.

Helix lamellosa Deshayes: Hist. Nat. Moll., vol. 1, p. 369 (French not Latin description).

Endodonta lamellosa Albers: Die Heliceen, p. 89, 1850. 
In the Prodrome, Férussac described this species by name only, giving the locality as "Islands of the South Sea." In the reports of Freycinet's voyage, he republished this species and refers to the plate and figure in the Histoire Naturelle des Mollusques, but gives "Port Jackson and the Islands of the Great Ocean" as the habitat. On the same page, under $H$. contorta, he furnishes a short description of $H$. lamellosa, mentioning only that it is "prettily spotted" and has "eight elevated lamellae obstructing its aperture." He also states that the specimens are young and compares this species with Helix albella.

In 1845 Pfeiffer (4) described this species, undoubtedly from specimens in his collection and quoted this description in all its essential characters in two later publications $(5,6)$. Deshayes (1) quotes Pfeiffer's Latin description in the Histoire, but has rewritten a rather full description in French. As this description differs in a number of essential characters from the description by Pfeiffer, I feel quite certain that it is from the original material which served as the model for the figure in the Histoire.

If Pfeiffer's description is based on the shell figured in the ConchylienCabinet (5) these references to lamellosa should be dropped. Judging from these figures, the specimen was close to if not identical with $H$. marsupialis described by Pilsbry and Vanatta in 1905. The proportionately high spire, flatter base, the narrow umbilicus and the prolongation of the aperture onto the edge of the umbilicus, as shown in Pfeiffer's figure 9, lead me to this conclusion, as these are a combination of characters that do not occur in the species figured by Férussac.

Tryon (11) quotes the more important characters of Pfeiffer's description and reproduces his figures.

From the rules of nomenclature Férussac's figure in the Histoire has precedence over Pfeiffer's description in Zeitschrift für Malakologie and Pfeiffer's figure in the Conchylien-Cabinet.

Pilsbry's figures of E. lamellosa (8) are undoubtedly drawn from specimens referable to $E$. fricki. The form and proportional size of the umbilicus, the suffused brownish color of the base, and the two outer smaller and more deeply seated basal laminae are a combination of characters of a geographical race abundant in the western valleys of the Waianae Mountains back of Mokuleia.

In 1905 Pilsbry and Vanatta (9) refigured lamellosa from specimens reported from the island of Kauai and referred specimens from the Waianae Mountains and also from West Maui to this species. The figured specimen has all the characters of a shell from the Waianae Mountains. The relatively wider spiral terrace extending into the umbilicus for about $13 / 4$ whorls, the proportional height of the spire, and the large size $(9.5 \mathrm{~mm}$. in diameter, $61 / 2$ whorls) of the shell are a combination of characters at 
present only known in shells from the Waianae Mountains. Both of the Kauaian species, of which I have examined a number of series, both recent and fossil, are characterized by having at least the post-nuclear if not all the whorls transversely costate or distinctly striate.

In 1871 Pease (3) united E. fricki and E. lamellosa. In this he was followed by Sykes (10), who added Mount Kaala of the Waianae Mountains and the mountains of Lanai to the habitats. But I see no justification for uniting them.

Judging from Férussac's figure of what was undoubtedly the type specimen, I am fairly certain that this specimen came from the slopes of Mount Konahuanui, the highest peak of the Koolau Range. In the collection of Bernice P. Bishop Museum are several small lots of this species from this locality. They are not abundant; but specimens are found on and under dead leaves and twigs at and near the top of the peak, within an area of not more than 200 to 300 square yards. In only one other locality of which I have any knowledge are shells approaching Férussac's figures-the top of Puu Kahuauli, about three miles distant from Konahuanui, at the western head of Kalihi Valley. I have examined only two specimens from this locality, one collected by Gouveia and the other by Wilder. They are not typical according to Férussac's figures and can be considered as a geographical race.

\section{Shell, Characters}

Férussac's figures closely represent most of the specimens collected on Konahuanui. The almost flat spire, only slightly elevated, the high base below the peripheral keel, forming an inverted truncate cone, and the shape, formation, and size of the umbilicus are characteristically portrayed. In addition to these structural features, the color and markings are similar to some of the specimens before me. However, the bases of most specimens in the Museum are covered with a buffy citrine uniform epidermis, with only faint indications of maculated lines.

In most specimens of E. lamellosa from Konahuanui with more than $5 \frac{1}{2}$ whorls there is a very narrow spiral terrace from a third of a whorl to a whorl long. The width of this terrace varies in different specimens. In all it is formed by the undercutting of the columellar wall bordering the umbilicus, the outer and upper edge being slightly more contracted than the inner edge. In Férussac's figure the umbilicus is approximately 28 per cent of the greatest diameter. In four adult specimens (Bishop Museum Nos. $14265,16656,17606)$ the umbilicus measured from 27.5 to 29 per cent of the greatest diameter of the shell.

The height of the spire varies slightly, in some specimens being almost flat, in others only slightly raised. The whorls as a rule are separated by 
a very superficial suture, for they are united on almost the same plane. In a few older specimens the last whorl descends slightly for its last third, overhung by the periphery of the penultimate whorl.

None of the specimens examined has seven shorls, the number given by Deshayes. The greatest number, $63 / 4$ whorls, was found in two individuals (Nos. 17606 and 14265).

All the specimens of E. lamellosa in the Bishop Museum are apparently much shorter than the one measured by Deshayes. The greatest height of any in the Bishop Museum is $3.2 \mathrm{~mm}$. Deshayes gives $4 \mathrm{~mm}$. as the height of his shell, which is slightly more than half the greatest diameter. A careful measurement of his figure shows the height to be 44 per cent of the diameter, which coincides almost exactly with the measurements of the two largest shells in the Museum, given below. The measurements in millimeters of four adult shells are as follows:

$\begin{array}{cccc}\begin{array}{c}\text { CATALOG } \\ \text { NUMBER }\end{array} & \text { HEIGHT } & \begin{array}{c}\text { GREATEST } \\ \text { DIAMETER }\end{array} & \begin{array}{c}\text { NUMBER OF } \\ \text { WHORLS }\end{array} \\ 14265 & 3.2 & 7.1 & 63 / 4 \\ 16656 & 3.0 & 6.7 & 6 \\ 17606 & 3.0 & 6.8 & 6 \\ 17606 & 3.1 & 7.0 & 63 / 4\end{array}$

Unfortunately the folds of Férussac's much enlarged figure are not drawn with as much detail as could be wished. The relative position and size of the folds are well represented; but the details of the form of the individual folds have not been brought out.

According to Férussac's figure there are two parietal lamellae, one columellar fold, four basal and one palatal lamina. Of the 97 specimens of this species from Konahuanui, in Bishop Museum, only one shows an adventitious lamella. In this specimen the columellar fold is duplicate. In all the specimens two parietal lamellae are present, the outer much stronger than the inner, and with its free margin bifid. The smaller inner lamella is arcuate in cross section, and bent slightly inward. The columellar fold, situated near the base of the columella, slopes upward.

There are four nearly equally developed basal laminae, the innermost sloping outward, the three others nearly perpendicular to the base. The two inner are inserted at about an equal distance from the margin of the aperture, the third and fourth at somewhat increasing distances internally. In addition to these four basal laminae, 72 of the 97 specimens have a very short, low fold placed farther inwards between the fourth lamina and the peripheral keel. This fifth fold seems to have escaped the attention of former observers. In all specimens the upper parietal wall is furnished with two unequal laminae: a large one centrally situated and a much lower 
short one deeply seated and midway between this lamina and the peripheral keel.

In Férussac's figure the columellar fold is placed higher than has been observed in any Oahuan Endodonta, showing relationship with lamellosa. The inner lower corner of the aperture as drawn is similar to that in the Konahuanui specimens.

A comparison of the specimens in the Bishop Museum with Férussac's figures makes me feel quite certain that Férussac's type colony is either identical with that from which the Museum specimens were obtained or
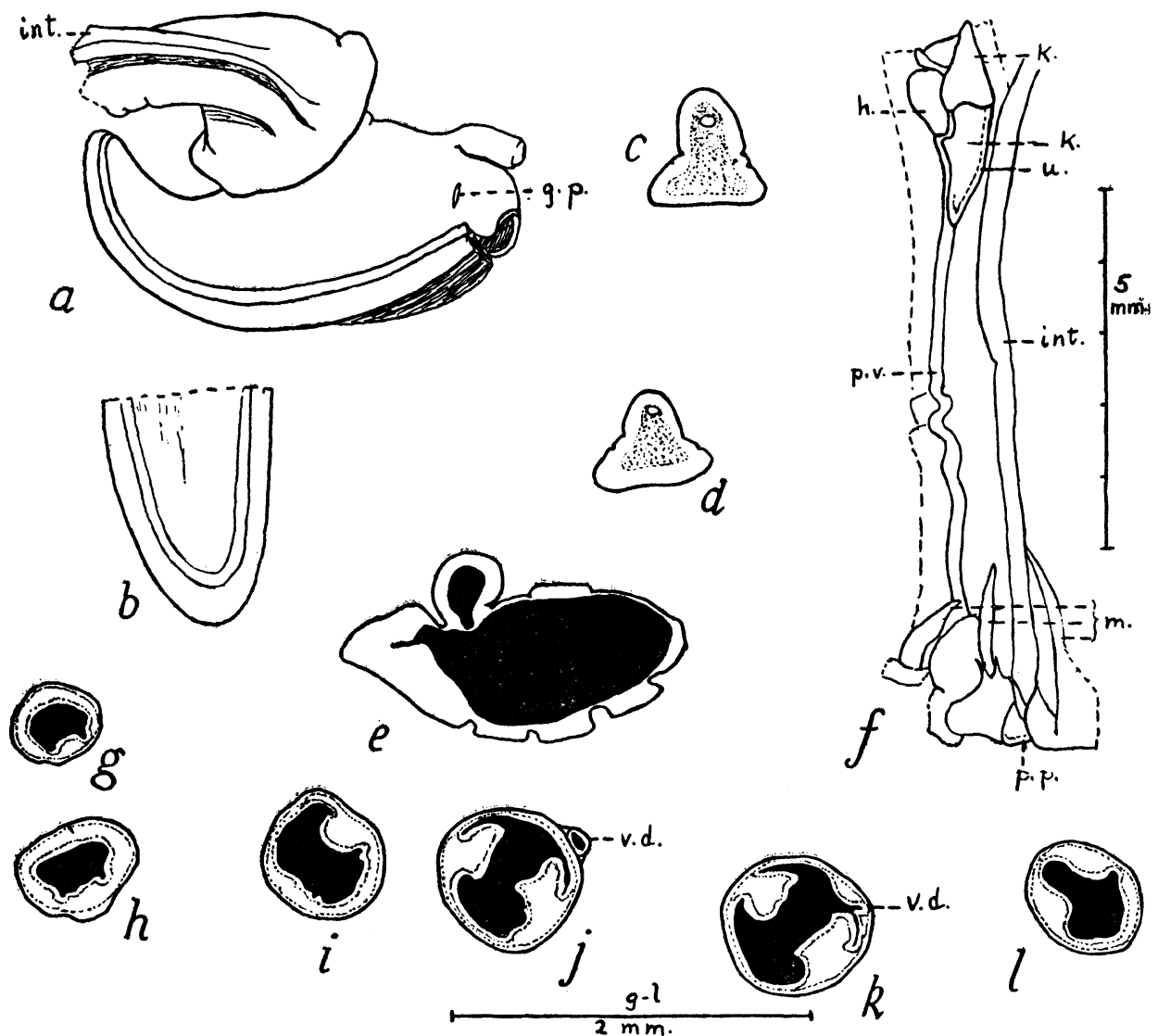

FIGURE 3.-Endodonta lamellosa Férussac: a, diagrammatic drawing of a nearly fully expanded alcoholic specimen, g. p. = genital pore, int. = intestine; $b$, end of tail, showing pedal grooves; $c$, cross section of foot just back of peduncle; $d$, cross section of foot about one-half distance between peduncle and tail; $e$, cross section of mantle just above collar, showing indentations of lamellae; $f$, pallial organs and alimentary tract, $\mathrm{h} .=$ heart, int. = intestine, $\mathrm{k}$. $=$ kidney, $\mathrm{m} .=$ muscles between lamellae, p. p. $=$ pulmonary pore, p. v. = pulmonary vein, u. = ureter; $g$ - $l$, cross sections of penis in figure $5, d-g$ at I, $h$ at II, $i$ at III, $j$ at IV, $k$ at V, $l$ at VI. 
that it is situated at no great distance, probably less than a quarter of a mile, though it may have been at a somewhat lower altitude. There is little doubt that both belong to the same geographical race.

\section{Sof't Anatomy}

The external portion of the animal is uniformly whitish with a slight yellowish tinge. The pedal grooves are shallow and very narrow but easily made out. Their position is shown in figures $3, b, c, d$. The sole is narrow and nearly smooth. The surface above the pedal grooves is very minutely granulose. The genital pore is placed very far forward and is almost under the base of the tentacle (fig. 3, a).

The mantle is thin, colorless, and strongly indented where it meets the apertural folds (fig. 3,e). The lung cavity is long and narrow. The pulmonary vein is well defined and extends nearly to the collar. The kidney is long and narrow, and the urethra crosses over from near its base to under the intestine (fig. $3, f$ ).

The genital organs are remarkably simple (fig. 5). The penis is longcylindric, tapering gradually towards the base, where it narrows rapidly just above the genital pore. Ordinarily it is widest where the vas deferens enters and does not taper to any extent above; the distal end is rounded. Three penes had the following measurements:

Specimen B: length 5.3 , diameter $0.8 \mathrm{~mm}$. (fig. $5, a, b$ )

Specimen A: length 6.1 , diameter $0.9 \mathrm{~mm}$. (fig. $5, d$ )

Specimen C: length 4.4 , diameter $0.7 \mathrm{~mm}$. (fig. 5, c)
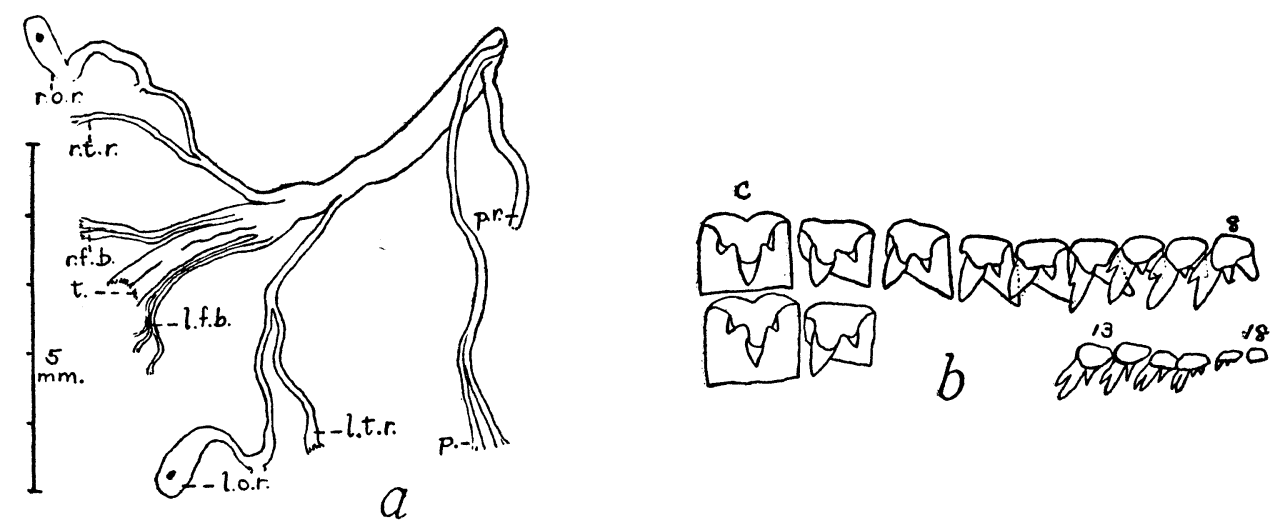

Figure 4.-Endodonta lamellosa Férussac: a, free muscles, p. r. = penis retractor, p. = pharyngeal retractor, 1. t. r.= left tentacular retractor, 1 . o. r. $=$ left ocular retractor, 1. f. b. = left front body retractor, t. $=$ tail retractor, r. f. b. $=$ right front body retractor, r. t. r. = right tentacular retractor, r. o. r. = right ocular retractor; $b$, teeth, C-8, 13-18, geatly magnified. 
The penis retractor is attached to the distal end of the penis. The vas deferens enters the penis at from a third to a quarter the distance from its distal end. In cross section the lower portion of the penis is a simple tube, but upwards two well-developed pilasters are gradually formed (fig. $3, g-l$ ).

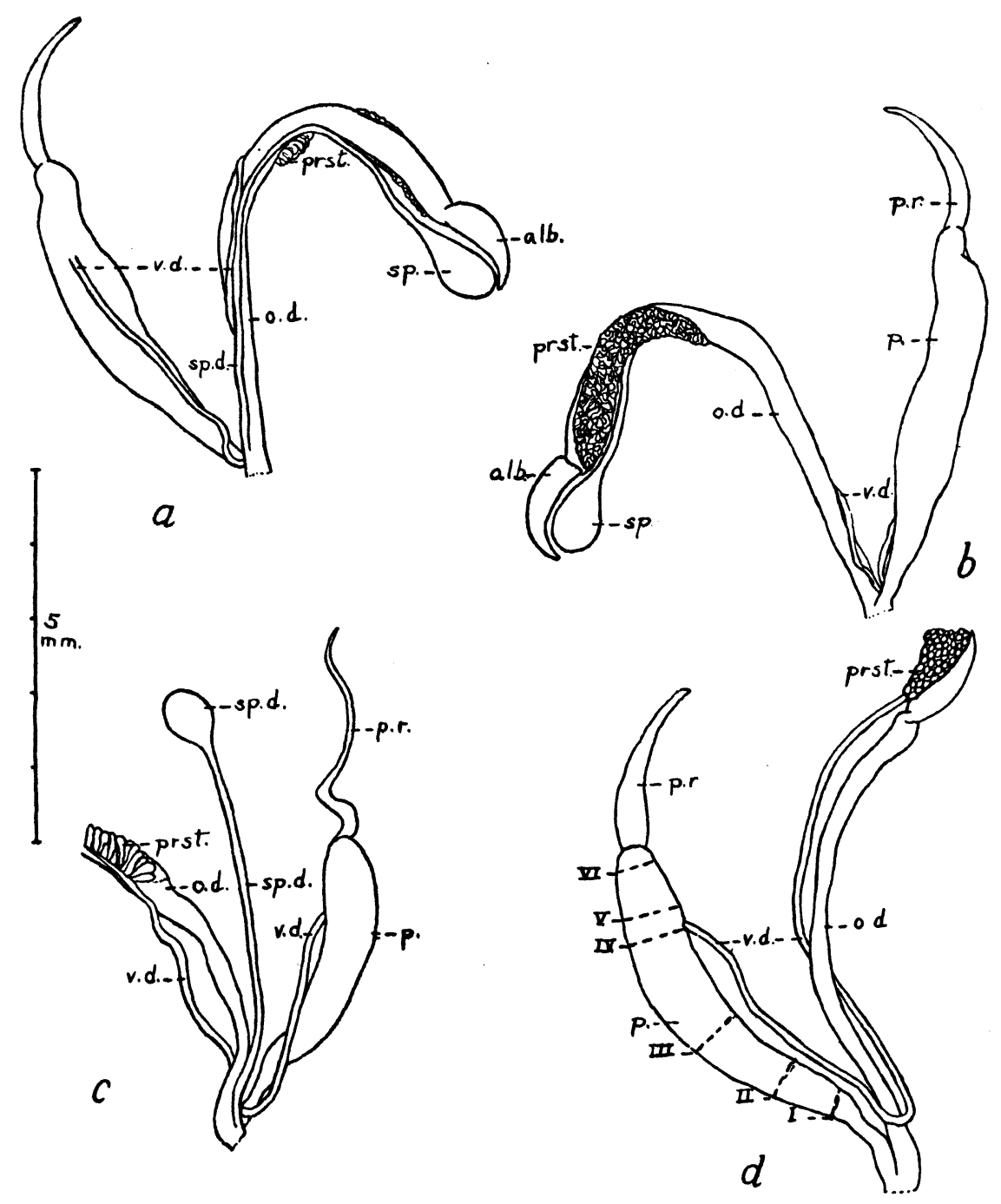

Figure 5.-Endodonta lamellosa Férussac, reproductive organs: a, lower view, hermaphrodite organs omitted, Specimen $B$, alb. $=$ albumen gland, sp. = spermatheca, prst. $=$ prostate, o. d. $=$ oviduct, v. d. $=$ vas deferens, $\mathbf{s p . ~ d . ~ = ~ s p e r m a t h e c a ~ d u c t , ~}$ p. $=$ penis, p. r. $=$ penis retractor; $b$, reproductive organs, upper view, hermaphrodite organs omitted, same specimen, lettering as in $a ; c$, upper view, upper female organs omitted, Specimen C., lettering as in $a ; d$, lower view, upper female organs omitted, Specimen A., lettering as in $a$. 
The oviduct is simple, long, and narrow, the upper third covered towards the outside with a well-developed, narrow, granular prostate gland; adjoining the distal end of the oviduct is a rather large albumen gland. The spermatheca is pyriform and lies just under the albumen gland. It is furnished with a long narrow duct, which is inserted into the uterus just above and close to the genital pore.

The penis retractor is attached close to the distal end of the free muscles and just below the attachment of the pharyngeal muscles. The left tentacular muscle is attached to the free muscle somewhat more distally than the right tentacular (fig. 4, a).

The radula is long and narrow. The tricuspid centrals are furnished with a large square basal plate. There is a gradual transition between the laterals and marginals. Beginning with the third lateral the diminution in the size of the basal plate increases. The fifth tooth has the mesocone slightly notched on its inner edge. The notch increases in size to about the fourteenth or fifteenth tooth, where the mesocone is divided into two almost equal cusps. Just beyond these the ectocone splits into two minute cusps. The three or four outermost marginals are ordinarily very minute squarish plates without cusps (fig. $4, b$ ).

The tooth formulae of five specimens examined are 1-4-16 (two specimens), 1-4-18 (two specimens), and 1-4-19 (one specimen).

The jaws were very thin and delicate and were not isolated.

\section{Conclusion}

For the identification of E. lamellosa the figures published by Férussac in the Histoire and Deshayes's French description should be relied on. The Latin description in the Histoire should be ignored, as it is taken directly from Pfeiffer, whose description is based on an entirely different species, probably E. marsupialis. Pilsbry's and Vanatta's figures illustrating $E$. lamellosa are also drawn from another species, undoubtedly E. fricki or one of its close relatives.

\section{ENDODONTA MARSUPIAI.IS}

\section{Endodonta marsupialis Pilsbry and Vanatta}

Endodonta marsupialis Pilsbry and Vanatta: Acad. Nat. Sci. Philadelphia, Proc. 1905, p. 784, $1905-06$.

Helix lamellosa Pfeiffer: Helix II, Conch.-Cab. of Martini and Chemnitz, p. 197, pl. 100, figs. 6-9.-Tryon: Man. Conch., vol. 3, p. 67, pl. 12, figs. 32-34, 1887.-Pfeiffer : Zeitschr. f. Malak., p. 85,1845 ; and Mon. Hel., vol. 1, p. 184, 1848, if these two descriptions are based on the specimen figured in Helix II, Conch.-Cab., pl. 100, figs. 6-9.

The species Endodonta marsupialis was described by Pilsbry and Vanatta from specimens collected on Oahu. Dr. Pilsbry kindly deposited two of the 
paratypes in the Bishop Museum. On the western slope of Mount Tantalus, directly above the floor of Pauoa Valley on the trail leading to the southern extremity of the peak, I located a small colony of the species. In two trips only 69 live and whole dead specimens were found. Two small series that came to the Museum with the $H$. Waterhouse collection were probably obtained in the immediate neighborhood.

\section{Sheil Characters}

The species is easily recognized by its proportionately narrow umbilicus and rather high spire.

Of the 86 specimens from all sources that I have examined, only 2 have a fifth minute deeply seated outer basal lamina. In this respect the species differs from E. lamellosa, in which in nearly three-fourths of the specimens examined this tooth was present. Somewhat less than half the specimens (35) have only a single upper palatal plica. The small, deeply seated outer palatal plica, present in every specimen of E. lamellosa examined, is present in 51 specimens (59 per cent) of E. marsupialis.

A character that this species has in common with Tahitian and Cook Islands Libera, but in a less marked degree, is the prolongation of the lower inner margin of the aperture (below the columellar fold) into a distinct sinus, which extends to and forms the termination of the angle bordering the umbilicus. This sinus is merely indicated but not developed in specimens of E. lamellosa.

Adult shells of E. marsupialis are slightly larger than those of E. lamellosa with approximately the same number of whorls. Measurements in millimeters are as follows:

$\begin{array}{lccc}\text { CATALOG } & \text { HEIGHT } & \text { DIAMETER } & \text { NUMBER OF } \\ \text { NUMBER } & 3.6 & 7.6 & \text { W HORLS } \\ 16118 & 3.8 & 7.8 & 63 / 4 \\ 16118 & 3.7 & 8.1 & 61 / 2 \\ 16118 \text { dead } & 3.7 & 8.2 & 63 / 4 \\ 16118 \text { dead } & & & 61 / 2\end{array}$

\section{Soft Anatomy}

Externally there is no observable difference between the animals of $E$. marsupialis and E. lamellosa. In E. marsupialis the reproductive organs, proportional to the size of the animal, are much larger. The oviduct is somewhat longer and is distinctly twisted or kinked. The spermatheca and albumen gland are decidedly larger. The hermaphrodite duct is a simple curved tube, widest near its middle and tapering towards both ends. A single specimen of the hermaphrodite gland dissected was found to consist of 20 two- to four-branched follicles. 
The penis differs considerably in the two species under discussion. That of E. marsupialis is long and slender and is ordinarily folded two to three times. The two specimens figured measured approximately 12.0 by 1.0 $\mathrm{mm}$. and 15.0 by $0.8 \mathrm{~mm}$. (See fig. $6, a, b$.) A third specimen, carefully pinned out, measured $14 \mathrm{~mm}$. in length. In Specimen B (the more characteristic of the two figured specimens) from the point where the vas deferens enters it, the penis tapers gradually towards its distal end, where the penis retractor is attached. Below the entrance of the vas deferens the penis has an almost

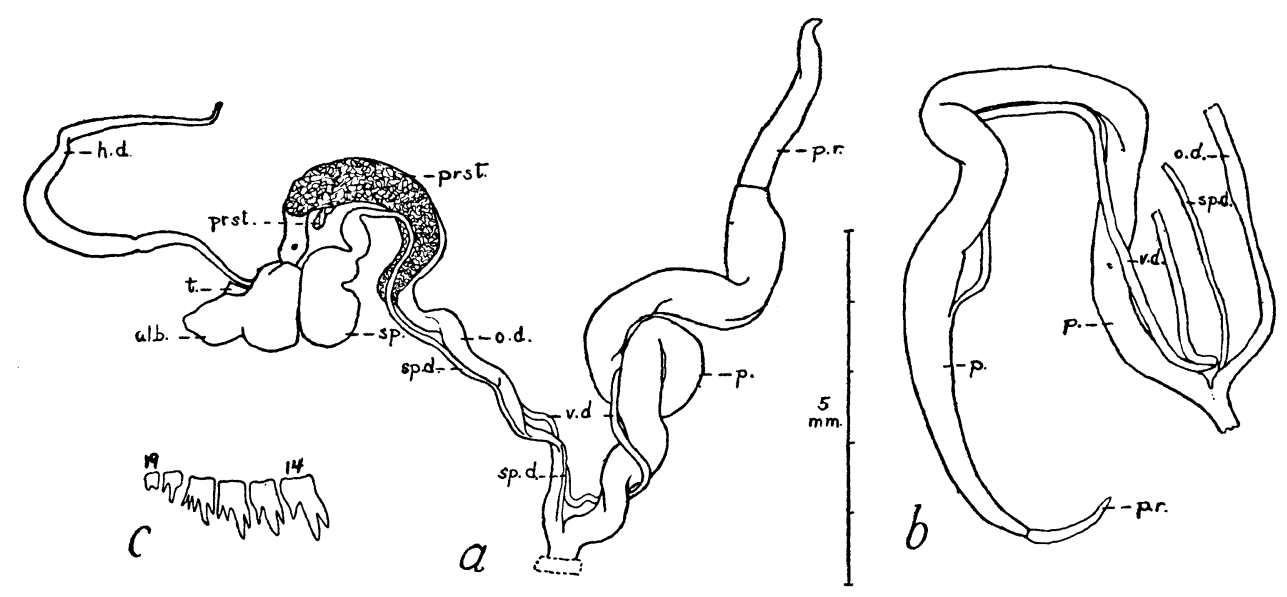

FIGURE 6.-Endodonta marsupialis Pilsbry and Vanatta: $a, b$, reproductive organs, alb. = albumen gland, h. $=$ hermaphrodite duct, o. d. $=$ oviduct, p. $=$ penis, prst. $=$ prostate gland, p. r.= penis retractor, sp.= spermatheca, sp. d. = spermatheca duct, t. $=$ talon, v. d. $=$ vas deferens $; c$, marginal teeth, $14-19$, greatly magnified.

uniform diameter to a point directly above the genital pore, where it narrows gradually. The vas deferens enters the penis about $3.5 \mathrm{~mm}$. from its distal end. In cross section the penes show an internal formation of pilasters similar to those of E. lamellosa. In form and size the penis of E. marsupialis approaches closer to E. fricki than to E. lamellosa. It differs, however, from E. fricki in that the vas deferens enters the penis at a proportionately greater distance from its distal end.

The tooth formula of the radula of E. marsupialis differs slightly from that of E. lamellosa. Three radulae have the following formulas: 1-5-18, 1-5-17, and 1-5-20. All three radulae of E. marsupialis examined have five laterals; while E. lamellosa has four. The centrals and laterals are both characterized by rather wide basal plates. From the fourteenth to the seventeenth marginals the cusps are more numerous and much more strongly developed in E. marsupialis than in E. lamellosa. (See fig. 6, c.) 


\section{Conclusion}

The species E. lamellosa and E. marsupialis differ not only in shell characters but also decidedly in the size and form of their reproductive organs, especially the male organs. In the arrangement and form of some of their teeth are also some slight differences.

\section{ENDODONTA FRICKI}

\section{Endodonta fricki Pfeiffer}

Helix fricki Pfeiffer: Zool. Soc. London, Proc. 1858, pp. 21-22, pl. 40, fig. 3.Tryon: Man. Conch., vol. 3, p. 67, pl. 12, figs. 35 and 36, 1887.

Endodonta lamellosa Pease: Zool. Soc. London, Proc. 1871, p. 474.-Pilsbry: Man. Conch., vol. 9, pl. 4, figs. 40 and 41, 1894.-Sykes: Fauna Hawaiiensis, vol. 2, part 4, Mollusca; p. 287, 1900.-Pilsbry and Vanatta: Acad. Nat. Sci. Philadelphia, Proc., 1905, p. 783 , pl. 43 , figs. 7 and $8,1905-1906$.

The name Helix fricki was proposed by Pfeiffer in 1858 . That the illustration accompanying the description was undoubtedly drawn from a specimen from the Waianae Mountains is the conclusion reached after a comparison of both the description and figure with the large series of typical Endodonta from the Waianae Mountains in the collection of the Bishop Museum. The several hundred specimens in the series were found in about 67 restricted colonies covering the whole length of the range. Included in the series are a number of geographical races, whose relationships to what are apparently distinct species are somewhat involved.

\section{Shell Characteres}

Taken together Pfeiffer's description and figure do not exactly fit any one of the geographical races represented in the collection of the Bishop Museum.

The post-nuclear whorls of some of the Waianae forms related to fricki are indistinctly costulate, the others are very faintly and irregularly striate. None of the numerous specimens that have come under my observation has the suture margined nor subexcavated as mentioned by Pfeiffer. Many individuals have the last whorl slightly bent downward, and in these the carina of the penultimate whorl overhangs the last whorl. In no specimen that I have examined has the columellar fold been absent. In some individuals it is placed near the base of the columella, in others its position is about midway. I agree with Dr. Pilsbry that the absence of this fold is pathologic.

The figures published by Pilsbry and Vanatta show the characteristics of one of the many Waianae forms. None of the specimens in Bernice P. Bishop Museum with a diameter of $8 \mathrm{~mm}$. has as many as seven whorls, 
the number recorded by Pfeiffer. With this diameter the most typical races have only from $53 / 4$ to $61 / 2$ whorls. Specimens from Pukaloa and Mokuleia in the Waianae Mountains come fairly close in most characters to Pfeiffer's diagnosis, though they vary somewhat in measurements and in the proportional size of the umbilicus. Measurements in millimeters are as follows:

\begin{tabular}{|c|c|c|c|c|}
\hline LOCALITY & IGHT & DIAMETER & WHORLS & UMBILICUS \\
\hline $\begin{array}{l}\text { Pukaloa } \\
\text { Pukaloa } \\
\text { Pukaloa }\end{array}$ & $\begin{array}{l}2.7 \\
2.6\end{array}$ & $\begin{array}{l}7.2 \\
6.8\end{array}$ & $\begin{array}{l}6+ \\
6\end{array}$ & $\begin{array}{l}29 \\
27\end{array}$ \\
\hline $\begin{array}{l}\text { second colony (16019) } \\
\text { Pukaloa }\end{array}$ & 3.1 & 8.0 & $61 / 2$ & 36 \\
\hline \begin{tabular}{ll}
\multicolumn{2}{r}{ second colony $(16019)$} \\
Mokuleia & $(17215)$ \\
Mokuleia & $(17215)$
\end{tabular} & $\begin{array}{l}3.5 \\
3.4 \\
3.8\end{array}$ & $\begin{array}{l}8.7 \\
8.7 \\
8.2\end{array}$ & $\begin{array}{l}63 / 4 \\
61 / 2 \\
62 / 3\end{array}$ & $\begin{array}{l}40 \\
28 \\
25\end{array}$ \\
\hline
\end{tabular}

The two colonies from Pukaloa are not more than a few hundred yards apart, and yet their shells show considerable differences in the proportional size of the umbilicus. In the second colony the size of the umbilicus approaches that given by Pfeiffer.

In 44 specimens (catalog No. 14236) of E. fricki from the same colony as 14291,36 ( 82 per cent ) had but four basal laminae, 8 (18 per cent) had a fifth small outer deeply seated basal fold. In 92 specimens from Mokuleia (No. 17215) 54 specimens (59 per cent) had four basal laminae and 38 (41 per cent) had the additional basal fold. In the absence of the outer fifth basal fold most specimens of this species differ from lamellosa, in which this fold appears in nearly 75 per cent of the specimens. This tooth is more common in fricki than in marsupialis. Though of the 44 specimens in No. 14236 no adventitious lamellae were found, 11 specimens in No. 17215 showed abnormal lamella arrangement due to the addition of adventitious lamellae. In two specimens from this colony as many as 12 lamellae are present. The columellar fold is ordinarily situated slightly below the middle of the columella, in a few specimens almost basal in position. This character may have led Pfeiffer to state that the columellar fold is absent. As in lamellosa, there are always two upper palatal laminae, a large one centrally placed and a short, low one deeply seated, midway between the central and the peripheral keel. The more prominent upper palatal fold is characteristically formed in all the geographical races of $E$. fricki from the Waianae Mountains. Its free margin is abruptly bent outwards almost at right angles, so that in cross section it is $\mathrm{L}$ shaped. This character does not occur in either of the two species from the Koolau Range.

\section{Soft Anatomy}

Six specimens of one of the geographical races of E. fricki from Lualualei, on the south side of the Waianae Mountains, were dissected. The 
outside of the animal is similar to that of lamellosa and marsupialis. Some rather important differences exist in the reproductive organs. The prostate gland is proportionately longer and narrower than that of lamellosa. As in marsupialis, the penis is kinked or twisted. In length it is 9 to $10 \mathrm{~mm}$. and in size is intermediate between that of lamellosa and marsupialis. Unlike either of the other two species, the vas deferens of fricki enters the penis close to its distal end. In cross section the interior shows about the same muscle arrangement as in lamellosa. Another constant character found in this species is the numerous kinks or folds in the vas deferens in the region near the genital pore. (See fig. $7, a, b, d$.)
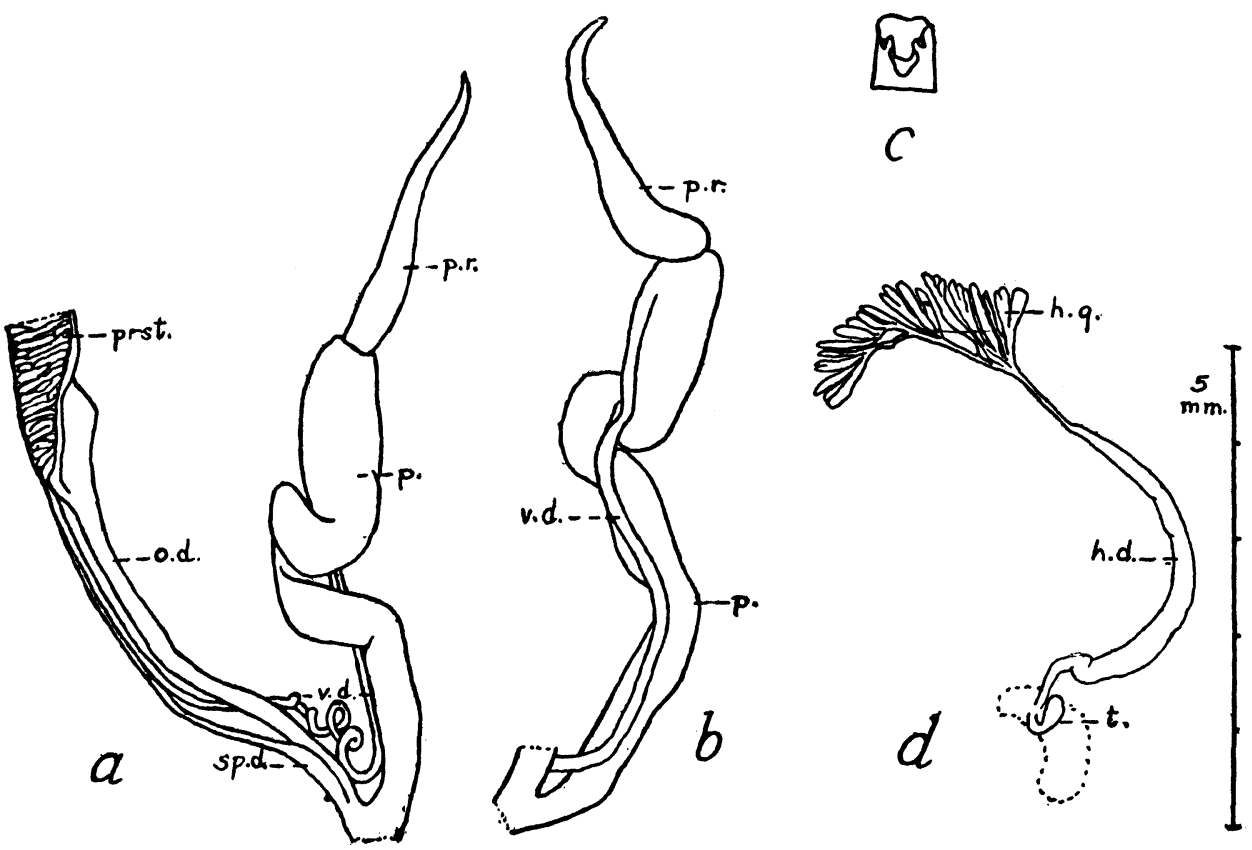

FIGURE 7.-Endodonta fricki Pfeiffer: $a$, reproductive organs, upper female organs omitted, o. v. $=$ oviduct, p. $=$ penis, prst. $=$ prostate gland, p. r. $=$ penis retractor, sp. d. = spermatheca duct, v. d. = vas deferens; $b$, male reproductive organs, lettering as in $a ; c$, central tooth, greatly magnified; $d$. hermaphrodite organs, $h$. d. $=$ hermaphrodite duct, h. g. = hermaphrodite gland, t. = talon.

The teeth of E. fricki are much smaller than those of E. lamellosa. In the two radulae examined the tooth formulae were 1-7-14 and 1-9-12. There are nearly twice as many laterals as in lamellosa. The basal plate of the centrals is proportionately much narrower, its width not quite equaling its length, whereas in lamellosa the basal plate is much broader than long. In both specimens of $E$. fricki the mesocone of the centrals extends slightly below the middle of the plate. The back of the centrals is not as concave 
as in lamellosa (fig. $7, c$ ). The side cusps of the centrals and the ectocones of the laterals and marginals are very minute, showing merely as points of light with the same magnification as that used in studying the radulae of lamellosa.

\section{ConcLusion}

From the characters given in Pfeiffer's diagnosis and in his figures I feel certain that his original specimens were from the Waianae Mountains of Oahu. Specimens agreeing exactly in all characters with his description and figure are not present in the collection of the Bishop Museum. Specimens from three colonies, however, agree closely enough to be chosen as representatives of his species. Not only the characters of the shells but also the anatomical differences lead me to believe that $E$. fricki should be considered distinct from E. lamellosa.

\section{BIBLIOGRAPHY}

1. DeshaYes, G.-P., Hist. Nat. Moll., vol. 1, p. 369.

2. Férussac, D. DE, Hist, Nat. Moll., pl. 51A, fig. 3.

3. PEASE, W. H., Catalogue of land shells inhabiting Polynesia: Zool. Soc. London, Proc. 1871, p. 474.

4. Pfeiffer, L., Zeitschr. f. Malak., p. 85, 1845.

5. Pfeirfere, L., Helix II: Conch.-Cab. of Martini and Chemnitz, p. 197, pl. 100, figs. 6-9.

6. PFEIFFER, L., Mon. Hel., vol. 1, p. 184, 1848.

7. PfEIFFER, L., Descriptions of eleven new species of land shells from the collection of H. Cuming, Esq.: Zool. Soc. London, Proc. 1858, pp. 21-22, pl. 40, fig. 3.

8. Pilsbry, H. A., Guide to the study of Helices: Man. Conch., vol. 9, pl. 4, figs. $40,41,1894$.

9. Pilsbry, H. A., and VanatTa, E. G., Hawaiian species of Endodonta and Opeas: Acad. Nat. Sci. Philadelphia, Proc. 1905, p. 783, pl. 43, figs. 7, 8, 1905-1906.

10. Sykes, E. R., Fauna Hawaiiensis, vol. 2, part 4, Mollusca, p. 287, 1900.

11. Tryon, G. W., Helicidae: Man. Conch., vol. 3, p. 67, pl. 12, figs. 35, 36, 1887. 


\section{DISTRIBUTION AND ANATOMY OF PUPOIDOPSIS HAWAIIENSIS}

BY C. MONTAGUE COOKE, JR., AND MARIE C. NEAL,

\section{DISTRIBUTION}

The only known species of Pupoidopsis, $P$. hazeaiiensis, described by Pilsbry and Cooke, ${ }^{5}$ is abundant on all the main Hawaiian islands wherever eolian calcareous "sandstone" occurs. In addition to the localities reported in the Manual of Conchology, specimens were taken later at Koloa, Mahaulepu, and Kealia on the Island of Kauai. All Hawaiian specimens are fossil. While on the Whippoorwill Expedition in 1924, T. T. Dranga
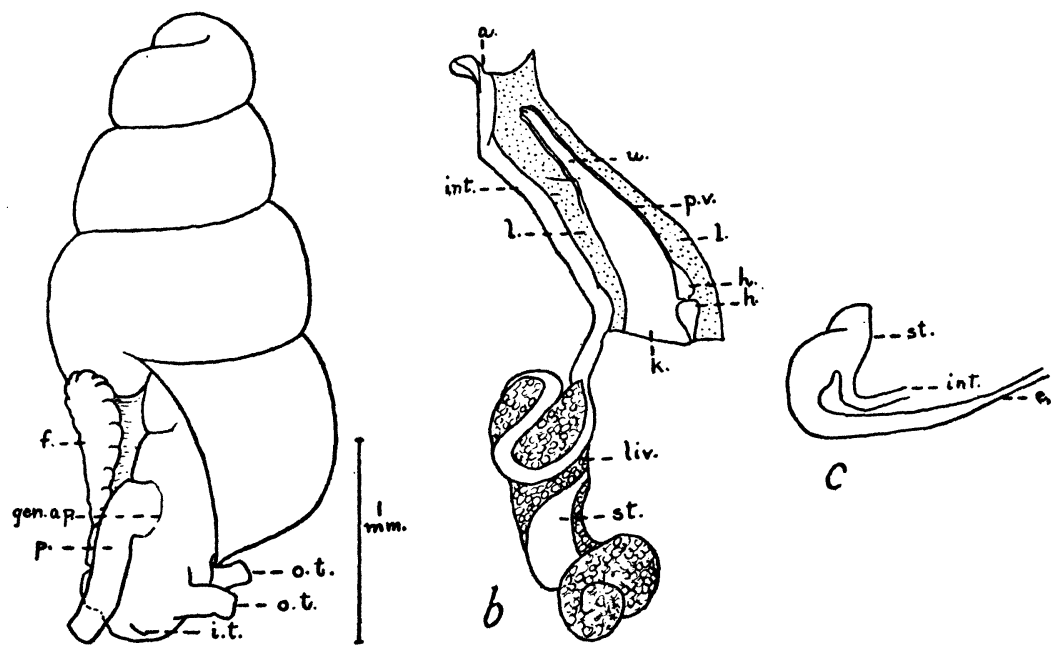

c

a

FIgURE 8.-Pupoidopsis hawaiiensis Pilsbry and Cooke: $a$, shell (No. 79467) with expanded animal, penis, and tentacles, f. $=$ foot, gen. ap. $=$ genital aperture, i. t. $=$ inferior tentacle, o. $\mathrm{t} .=$ ocular tentacle, $\mathrm{p}$. $=$ penis ; $b$, pallial organs and alimentary tract (No. 79490), a. = anus, h. = heart, int. $=$ intestine, k. = kidney, 1. = lung, liv. = liver, p. v. = pulmonary vein, st. = stomach, u. = ureter, greatly magnified; $c$, alimentary tract (No. 79490) showing stomach, greatly magnified.

found living specimens on Christmas Island, more than 1,200 miles distant from Hawaii. He collected them on bunch grass (Lepturus repens), on which they were very abundant, and later in the year S. C. Ball and G. P. Wilder collected more in several localities on the same island. The shells

- Pilsbry, H. A., Pupillidae: Man. Conch., vol. 26, pp. 106-108,1920-1921. 
agree with Hawaiian fossils and suggest the probable habitat of this species in the Hawaiian islands, where with the introduction of cattle and goats the bunch grass gowing on sand dunes has been destroyed. Thus since the advent of the white man the abundant fossil material has come into existence. The most recent Hawaiian shells were found on Molokai under fragments broken from ancient consolidated dunes. The absence of this species from Kahoolawe and Hawaii is probably due to the absence of such dunes on these two islands. It is found under similar conditions ${ }^{6}$ to the nearest related genus, Pupoides, a cosmopolitan genus.

The distribution of Pupoidopsis hawaiiensis on two land areas widely separated by ocean is remarkable. Its presence on Christmas Island is probably due to early Polynesian voyages from the Hawaiian islands, who do not seem to have carried it farther south, as the species has not been found on Malden or Penrhyn islands, where S. C. Ball made a special search for it. Neither has it been found on Palmyra, Washington, and Fanning islands, although many specimens of minute species of shells from these three islands are in the collection of the Bishop Museum.

\section{ANATOMY}

\section{GENERAL}

Judging by shell characters only, Pilsbry included Pupoidopsis in the subfamily Pupillinae, a classification that is further proved correct by the anatomy. For inferior tentacles are present and also an appendix to the penis.

The expanded animals (fig. 8, a), prepared by drowning in water and then preserving in alcohol, are light-slate on the sides of the foot and somewhat lighter on the sole. Indications of pedal grooves are lacking, and the sole is entire. In expanded animals the genital pore is midway between the inferior tentacles and the collar and just above the upper margin of the foot. The breathing pore is located in the collar above the right tentacle and is remarkably large. The ocular tentacles are somewhat darker than the foot, and in no specimen were the inferior tentacles expanded, though their position was clearly indicated (figs. 8, $a$ and 10, $a$ ). The exterior edge of the mantle is very dark slate. The wall of the lung is very thin and transparent, in some specimens scarcely pigmented, in others with lines of minutely pigmented dots accompanying the intestine, and in some bordering the lower margin of the kidney, the pericardium, and the pulmonary vein. The folds of the kidney, the position of the pulmonary vein, and the heart are easily seen through the very thin lung wall.

op. cit., p. 109. 


\section{JaW AND TEETH}

The jaw (fig. 10, $c$ ) is simple and semicircular and does not appear to have distinct vertical or arcuate striations. It is extremely tough and resists the action of potash when organic matter is being dissolved from the radulae. The radula is composed of almost transverse rows of teeth. The formula is $9-5-1-5-9$ (fig. 10, $d$ ). In some specimens are six laterals. The
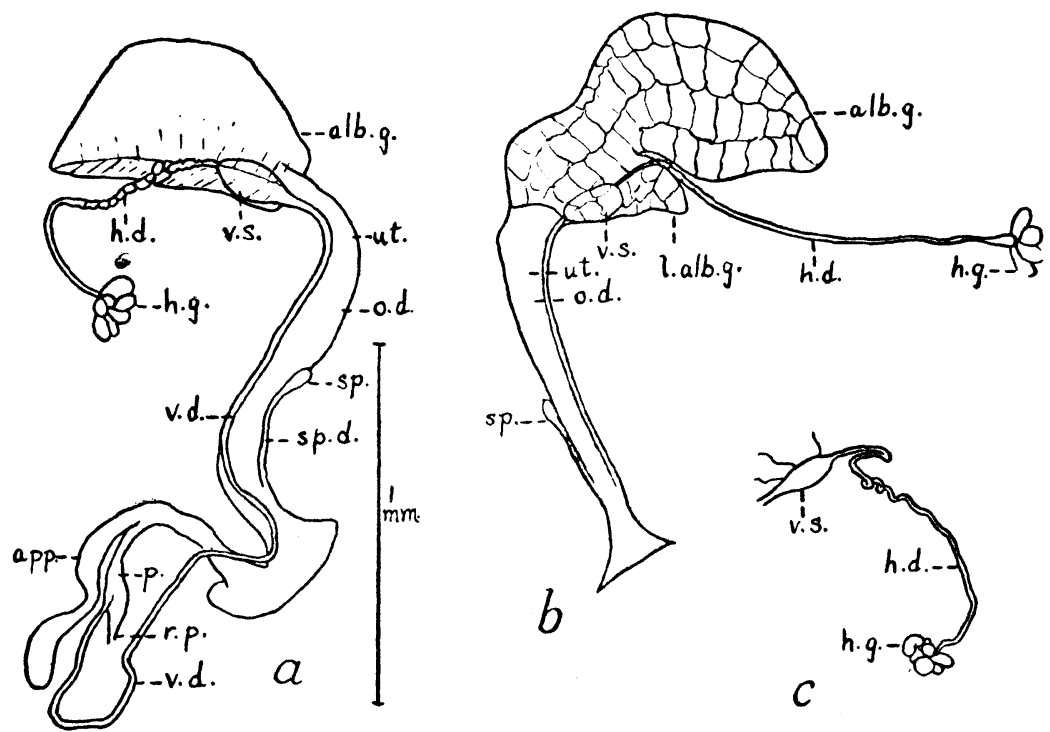

FIGURE 9.-Pupoidopsis hawaïensis Pilsbry and Cooke (No. 79490): a, male and female genitalia: alb. g. = albumen gland, app. $=$ appendix, h. d. $=$ hermaphrodite duct, h. g. $=$ hermaphrodite gland, o. d. $=$ oviduct, p. $=$ penis, r. p. $=$ retractor penis, sp. = spermatheca, sp. d. $=$ spermatheca duct, ut. $=$ uterus, v. d. $=$ vas deferens, v. s. = vesicula seminalis; $b$, female genitalia: 1 . alb. g. $=$ lobe of albumen gland, other lettering as in $a ; c$, detail showing hemaphrodite organ, h. d. $=$ hermaphrodite duct, h. g. = hermaphrodite gland, v. s. = vesicula seminalis.

centrals are minute, very indistinctly tricuspid with a narrowly oblong basal plate. The laterals are of the ordinary form and are bicuspid, the larger cusp extending to the base of the quadrate plate. The first marginal is a transition between the laterals and marginals. In this tooth the ectocone is ordinarily bifid. In the second, third, and fourth marginals the large cusps diminish and the outer cusps increase. The third marginal is indifferently three- or four-cuspid. Most of the outer marginals have four more or less equal cusps. The teeth have a superficial resemblance to those of Thaanumia fuscula. $^{7}$

'Pilsbry, H. A., and Cooke, C. M., Appendix to Amastridae. Tornatellinidae: Man. Conch., vol. 23, pl. 21, fig. 11, 1915-1916. 


\section{KIDNEY}

The kidney (fig. 8, b) is long and wide, diminishing gradually in width and ending in a rather short ureter. The several longitudinal folds of the kidney are very distinct. The ureter is much shorter than in Achatinellidae or Amastridae, and it terminates a short way back of the collar. A white line in the same position as the fleshy ridge in Achatinellidae accompanies the ureter on the side opposite the pulmonary vein, which accompanies the ureter without visible branching.

\section{Genitalia}

The male and female genitalia (fig. 9, a) open into an atrium and are slightly separated from each other. The right tentacle apparently passes between the penis on the inner side and the oviduct on the outer side. As in other Pupillids that have been examined, few animals have male genitalia. In most specimens dissected only female organs were present. The hermaphrodite gland consists of a single cluster of follicles radiating from the end of the hermaphrodite duct in both female and hermaphrodite specimens. The hermaphrodite duct is pigmented with black, its upper portion simple, its lower portion somewhat convoluted, which is different from specimens of Sphyradium described by Hanna. ${ }^{8}$ The proximal end is swollen and white and, as stated by Watson ${ }^{9}$ in regard to a similar organ in genera belonging to another subfamily of Pupillidae, probably functions as a vesicula seminalis (fig. 9, c). The albumen gland is very large, in some specimens pigmented inside and outside with black in a network pattern.' In the five female specimens dissected a flap was present (fig. 9, b) below the point of entry of the hermaphrodite duct and was absent in the four hermaphrodite specimens. From the narrow unconvoluted uterus the long narrow oviduct tapers towards the atrium, where it enlarges rather abruptly. The spermatheca is narrowly ovate, rather short stalked, about half as long as the oviduct, into which it apparently empties about one-sixth of the length of the oviduct back of the atrium. As far as the base of the albumen gland the female organs are enclosed in a tight, darkly pigmented sheath. A prostate gland was not discovered. The vas deferens passes down the oviduct, closely adhering to it, from the vesicula seminalis, with which it seems to be connected (fig. 9, $a$ ). It crosses the atrium and from there passes in a long loop, about twice the length of the penis, to the point of entry near the upper end of the penis. In female specimens the vas deferens seems to end near the lower part of the oviduct. The penis is simple and

\footnotetext{
'Hanna, G. D., The American species of Sphradium: U. S. Nat. Mus., Proc., vol. 41, p. $375,1911$.

"Watson, Hugh, Masculine deficiencies in the British Vertigininae: Malacological Soc. London, Proc., vol. 15, pp. 270-271, 1923 .
} 
cylindrical; it narrows just above its junction with the appendix and is slightly swollen above. The penis retractor is short and seems to be attached to the lung cavity just behind the collar. The appendix has a total length nearly equal to the total length of the penis. It is simple and slightly contracted near the middle. In a few specimens the penis is extruded (fig. 10, b), when it appears as a simple, straight or slightly arched sac, so transparent that vas deferens, retractor muscle, and appendix are plainly visible through it.

In comparison with genitalia of three genera of Vertigininae studied by Watson, ${ }^{10}$ those of Pupoidopsis differ considerably. It has a proportionately

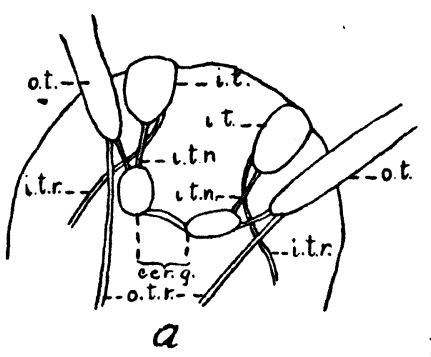

a

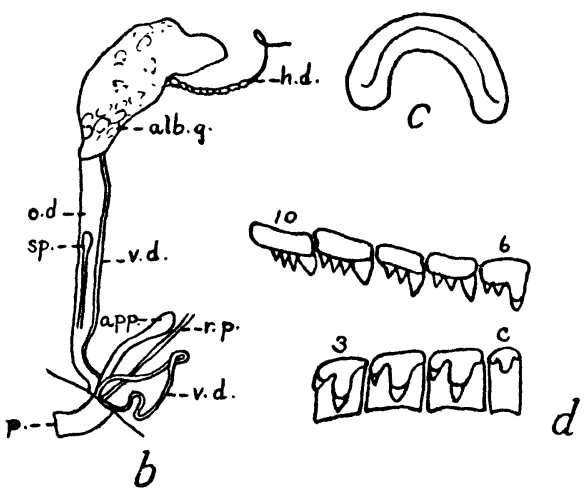

FIGURE 10.-Pupoidopsis hawaiiensis Pilsbry and Cooke: $a$, ocular and inferior tentacles $($ No. 79467$)$, cer. g. $=$ cerebral ganglion, i. t. $=$ inferior tentacles, i. t. n. $=$ inferior tentacular nerve, i. t. r. $=$ inferior tentacular retractor, o. t. $=$ ocular tentacle, o. t. n. $=$ ocular tentacular nerve, o. t. r. $=$ ocular tentacular retractor; $b$, male and female genitalia with penis partly extruded (No. 79490), letteringl as in fig. $9, a ; c$, jaw (No. 79490) (x 80); $d$, teeth (No. 79490).

larger albumen gland; narrower uterus; smaller hermaphrodite gland with terminal follicles in rosette formation, not clustered on one side of the end of the duct as in the genera studied by Watson; larger and lower vesicula seminalis; longer vas deferens, except in Vertigo, which has one of about the same length; and shorter spermatheca duct with lower attachment. The oviduct is not swollen. The penis is proportionately about the same length as that of Vertigo, but differs from that genus and from Columella and Truncatellina in two very evident ways: by having an appendix of substantial size (Vertigininae have none) and by having the openings of the male and female genitalia slightly separated in the atrium (they are joined a short way in Vertigininae). 


\section{SUMMARY}

Not only in shell characters but also in anatomy is Pupoidopsis closely related to Pupoides, a genus in the same subfamily. To genera in the subfamily Vertigininae Pupoidopsis is less closely related.

As in some Vertigininae, at least, the majority of specimens of Pupoidopsis hawaiiensis, well developed otherwise, lack male organs.

Female specimens differ from hermaphrodite by lacking penis and appendix and by having apparently a rudimentary vas deferens and a flap on the albumen gland. 


\title{
ANATOMICAL STUDIES OF ACHATINELLIDAE
}

\author{
BY MARIE C. NEAL
}

\section{COMPARISON OF REPRESENTATIVE SPECIES OF THE FAMILY}

In their monograph on the Hawaiian family of land mollusks, Achatinellidae, Pilsbry and Cooke ${ }^{11}$ dealt exhaustively with the shells. At two other times ${ }^{12}$ Pilsbry examined the animals of thirteen species or varieties, as follows:

\section{Name}

Newcombia philippiana (Pfeiffer)

Section Baldwinia

Partulina confusa (Sykes)

Section Partulinella

Partulina redfieldii var. kamaloensis

Pilsbry and Cooke

Partulina dolei (Baldwin)

\section{Section Bulimella}

Achatinella abbreviata Reeve

Achatinella viridans Mighels

Achatinella byronii (Wood)

Achatinella lila Pilsbry

Section Achatinellastrum

Achatinella stewartii (Green)

Achatinella vulpina (Férussac)

Section Achatinella

Achatinella lorata var. nobilis Pfeiffer Achatinella vittata var. simulans Reeve Achatinella mustelina Mighels

\begin{tabular}{|c|c|}
\hline Parts figured & Island \\
\hline Male and female genitalia & Molokai \\
\hline Male and female genitalia & Hawaii \\
\hline Male and female genitalia & Molokai \\
\hline $\begin{array}{l}\text { Male and female genitalia, } \\
\text { kidney, free muscles }\end{array}$ & Maui \\
\hline $\begin{array}{l}\text { Male genitalia } \\
\text { Male genitalia } \\
\text { Male and female genitalia } \\
\text { Male and female genitalia }\end{array}$ & $\begin{array}{l}\text { Oahu } \\
\text { Oahu } \\
\text { Oahu } \\
\text { Oahu }\end{array}$ \\
\hline $\begin{array}{l}\text { Male genitalia } \\
\text { Male genitalia }\end{array}$ & $\begin{array}{l}\text { Oahu } \\
\text { Oahu }\end{array}$ \\
\hline $\begin{array}{l}\text { Male and female genitalia } \\
\text { Male and female genitalia } \\
\text { Male and female genitalia }\end{array}$ & $\begin{array}{l}\text { Oahu } \\
\text { Oahu } \\
\text { Oahu }\end{array}$ \\
\hline
\end{tabular}

He compared the different organs, especially the genitalia, and found them so uniform that even the genera could not be distinguished. But as few specimens of a limited number of species were examined the question was not definitely answered: Do genera and species of Achatinellidae differ anatomically?

In an effort to answer this, examination was made of 97 specimens, including from one to four species of all sections of all genera, as shown in Table 5. The species were compared in a general way as to appearance and in detail as to shape of kidney, length of attachment of buccal and

11 Pilsbry, H. A., and Cooke, C. M., Achatinellidae: Man. Conch., vol. 22, 1912-1914. 1916.-Pilsbry, H. A., On the zoological position of Partulina and Achatinella: Acad. Nat. Sci. Philadelphia, Proc. 1900, pp. 565-567, pl. 17, 1961 
tentacular muscles, length of penis, length of appendix, diameter of prostate gland, and distance of beginning of spermatheca duct from the angle the oviduct makes with the penis. To all specimens examined the following statements apply:

1. In sinistral snails the genital pore was on the left, and the left tentacle passed between the penis and oviduct. The reverse was true in dextral snails. (No abnormally sinistral or dextral snails were dissected.)

2. Contraction of an animal into itself did not cause different measurements in organs from those of fully expanded animals.

3. The organs of pregnant specimens did not have different measurements from those of well-developed adults.

4. Each juvenile snail, with at least two whorls less than the adults, had proportionately to the size of the animal a much smaller prostate gland, much shorter appendix and penis (a condition that led to the investigation described on pages 44-49).
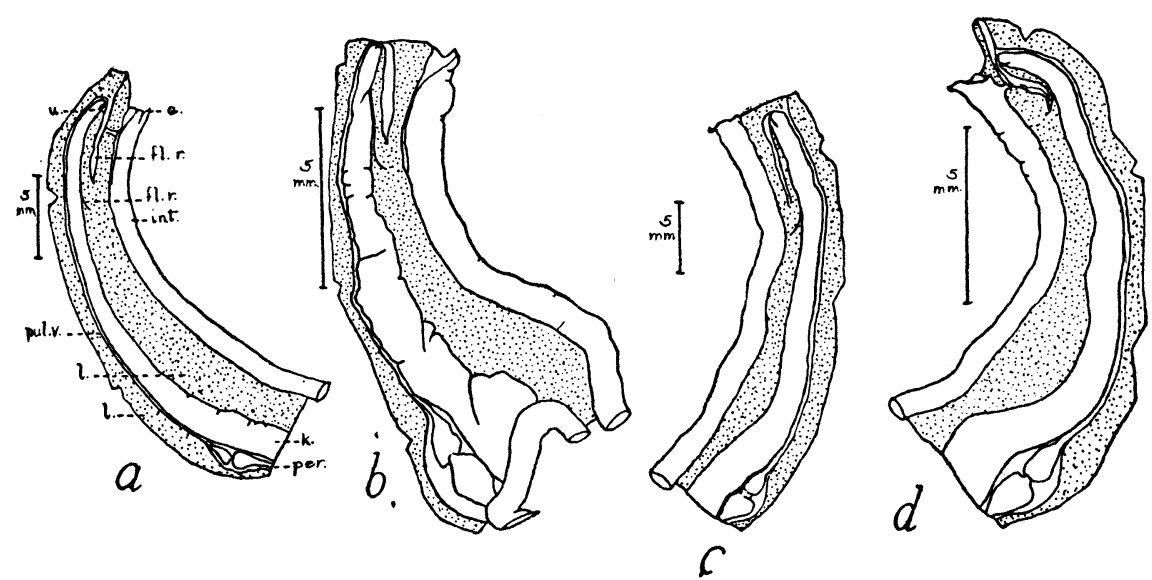

FIGURE 11.-a, Partulina redfieldii (Newcomb), pallial organs and alimentary tract, a. $=$ anus, fl. r. $\Longrightarrow$ fleshy ridge, int. $=$ intestine, $\mathrm{k} .=$ kidney, $1 .=$ lung, per. $=$ pericardium, pul. v. $=$ pulmonary vein, $\mathrm{u} .=$ ureter $; b$, Partulina horneri (Baldwin), pallial organs and alimentary tract (incompletely stretched); $c$, Partulina virgulata (Mighels), pallial organs and alimentary tract; $d$, Partulina mauiensis (Pfeiffer), pallial organs and alimentary tract.

The shape of the kidney varies slightly in width in all sections of Achatinella and Partulina, some species of different genera agreeing more closely than species of the same genus. (See figs. 11, 12.) In Newcombia the kidney was distinctly proportionately shorter. (See fig. 12, a.)

The lengths of attachment of two free muscles, buccal and tentacular, varied somewhat but overlapped in different species, depending on amount of contraction or expansion. In some Partulina these two muscles were 
attached for a longer distance above the distal end than in Achatinella, in most of which they were united closely for a short distance, loosely for a longer, or loosely all the way. An exception to this was P. mighelsiana, in which the two muscles were not attached.

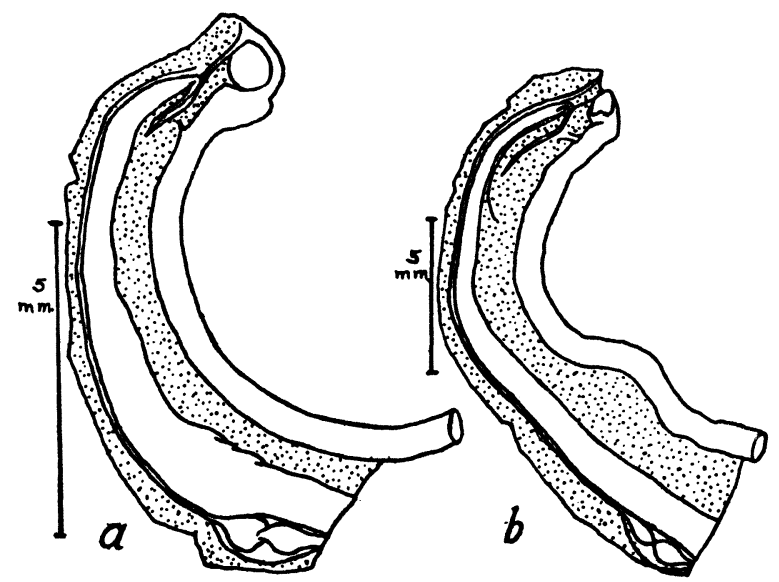

FIGURE 12.-a, Newcombia canaliculata (Baldwin), pallial organs and alimentary tract, the kidney appears narrow where bordered by pericardium, which overlies and partly conceals the actually broader end; $b$, Achatinella lehuiensis var. meineckei Pilsbry and Cooke, pallial organs and alimentary tract.

The male genitalia (figs. 13-15, 17) varied in size. With some exceptions the penis ranged in length from 6 to $13 \mathrm{~mm}$., in different species overlapping, being shortest in Partulina rufa (6 to 8), Achatinella vulpina (6 1/2 to $71 / 2$ ), A. lehuicnsis (5 $1 / 3$ to 6 ), and $A$. stewartii var. producta c. f.

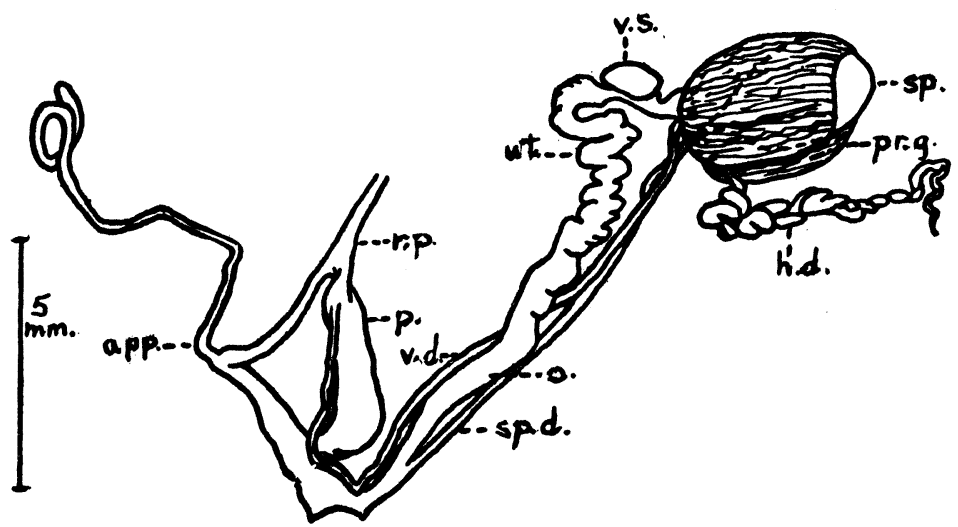

FigURE 13.-Partulina redfieldii (Newcomb), genitalia, app. $=$ appendix, h. d. $=$ hermaphrodite duct, $o .=$ oviduct, $\mathrm{p} .=$ penis, pr. g. $=$ prostate gland, r. p. $=$ retractor penis, sp. $=$ spermatheca, sp. d. $=$ spermatheca duct, ut. $=$ uterus, v. d. $=$ vas deferens, v. $s$. $=$ vesicula seminalis. 
dunkeri (6 to $62 / 3$ ). The exceptions were three species in the section Perdicella (3 to 5), Partulina horneri (3 $1 / 3$ to 4 ), Achatinella viridans ( 4 to 7 ), three species of Newcombia ( $21 / 3$ to $41 / 3$ ). The exceptions have the smallest or narrowest shells, excluding $P$. horneri, which has one of the largest and widest, and $A$. viridans.

The location of the penial retractor muscle was quite uniform, slightly on one side of the tip of the penis. Exceptions were: two Eburnella, slightly more on one side of the tip; Partulina dubia, Newcombia cumingi (fig. $15, d$ ), N. canaliculata, still more on one side. While the location seemed fairly uniform in all specimens of one species, in three specimens of $N$. pfeifferi the three different locations were found.

The branch of the penial retractor muscle between the penis and the appendix had different sizes and lengths, in the three Perdicella being small, short, tight, in some webbed to the penis, in some much contracted. As the webbed condition was found in juvenile Achatinella viridans (fig. 20), it is perhaps a juvenile character, significant of a low position of Perdicella in the scale of evolution of the family, a theory borne out by a juvenile feature of the adult shell, the thin unexpanded lip. In Partulina horneri this muscle was also short and tight, a state evidently caused by the shortness of the first division of the appendix or the low attachment of the muscle on this division. For in some animals the attachment was near the top, in others near the middle, in still others near the base of the division.

The appendix showed much variation in different species and owing perhaps to amount of contraction or expansion considerable variation in the same species. It has three distinct parts (fig. 14, b). The first, joining the penis proximally and supported by a branch of the penial retractor, was shortest in two-thirds of the specimens examined. Ordinarily it is nearly as wide as the penis. Distally it joins the second part, which in one-third of the specimens was shortest. Ordinarily this part is cylindrical in shape and tapers rather abruptly to its point of meeting with the long third division. This last division is a narrow tube of various lengths, and it gradually widens to about the same size as the second division, forms a cylinder, and ends in a rounded tip.

The three divisions, measured and recorded separately, had wide and overlapping lengths in the different species. The first division had a range overlapping between 2 and $72 / 3 \mathrm{~mm}$., except in the three Perdicella, Partulina horneri, $P$. nattii, $P$. proxima, and the three Newcombia, where it was shorter, and Partulina virgulata, where it averaged longer. The second division had a range overlapping between $11 / 3 \mathrm{~mm}$. and $63 / 4 \mathrm{~mm}$., the three Perdicella and three Newcombia having the shortest. The third division had a range between 11 and $32 \mathrm{~mm}$., the three Perdicella, Partulina horneri, Newcombia pfeifferi, and $N$. cumingi between 4 and $11 \mathrm{~mm}$. 
The prostate gland, ranging in diameter from 2 to $61 / 2 \mathrm{~mm}$., was smallest in the three Perdicella and three Newcombia, largest in Partulina rufa and Achatinella stewartii var. producta c. f. dunkeri. In proportion to the size of the animal it was about the same.

The spermatheca, which the prostate gland encloses, was oval or elliptical except in Partulina horneri, in which it was cylindrical, long, and narrow. It varied in size considerably, even in the same species, for exanple, in Achatinella viridans and Partulina virgulata.
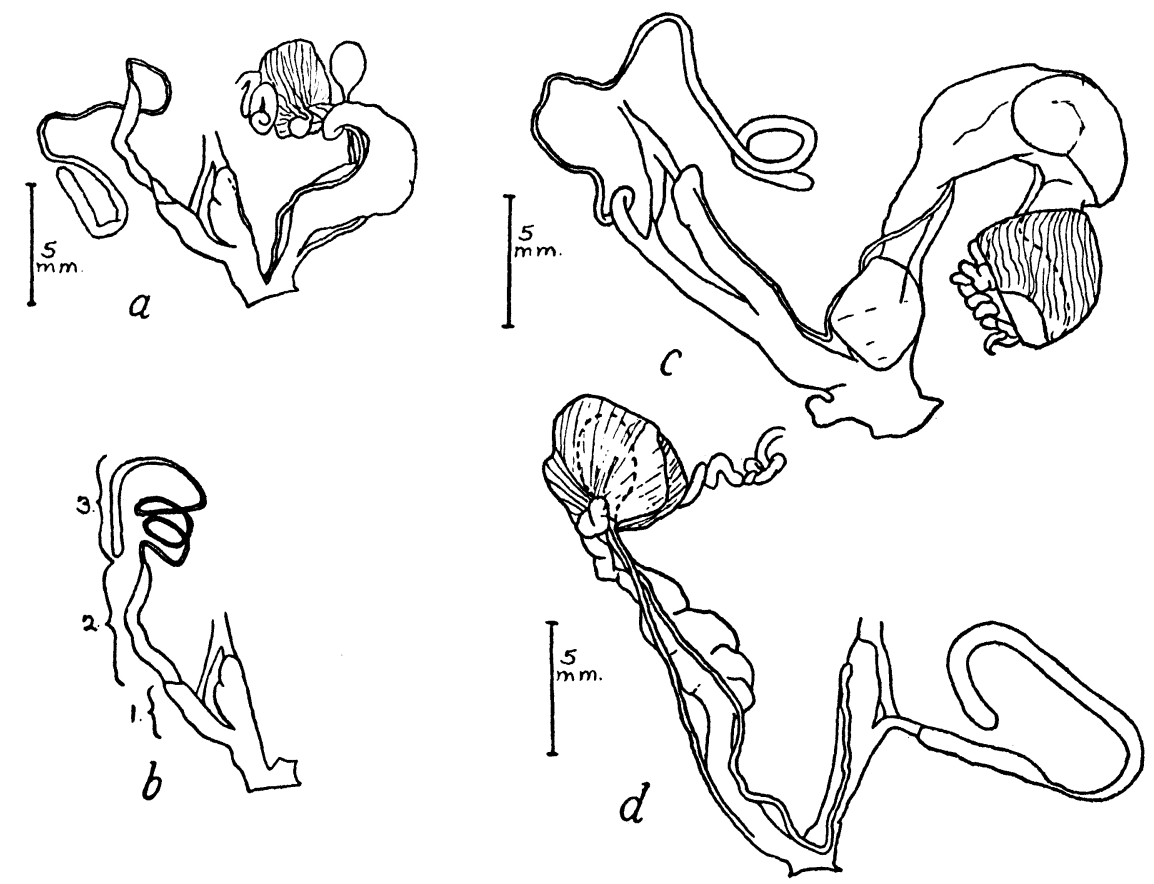

FIGURE 14.-a, Achatinella lehuiensis var. meineckei Pilsbry and Cooke, genitalia; $b$, Achatinella lehuiensis var. meineckei Pilsbry and Cooke, part of genitalia, showing three divisions of appendix; $c$, Partulina virgulata (Mighels), genitalia, one embryo in uterus, another about to escape from oviduct; $d$, Partulina rufa (Newcomb), genitalia.

The distance of the beginning of the spermatheca duct from the genital aperture and its origin on the side of the oviduct varied even in the same species, for example, in Achatinella vulpina from $21 / 2 \mathrm{~mm}$. to $51 / 3 \mathrm{~mm}$., in Partulina nattii from o to $11 / 3 \mathrm{~mm}$.

Comparison of my figures with those of Pilsbry listed on page 34 showed close agreement. The drawings of the genitalia of $P$. confusa gave an opportunity to compare them with the species of Baldwinia examined by me, with the result that they seem more like those of dubia than horneri in all ways except the, first division of the appendix, which is short, as in horneri. 
Genitalia of Newcombia philippiana resemble those of $N$. canaliculata. Pilsbry's drawings of genitalia of three species in the section Achatinella differ in length of penis and in first division of the appendix, which is very short in $A$. lorata var. nobilis. In lorata var. pulchella this was rather long. His representatives of the section Bulimella agree with my $A$. viridans except in the very narrow third division of the appendix of byronii. His $A$. stewartii was like my color form of that species, though in the species the length of the muscle connecting penis and appendix is not clear.

The divisions into sections and genera based on shell characters ${ }^{13}$ are hardly in agreement with the anatomy of those species that Pilsbry and
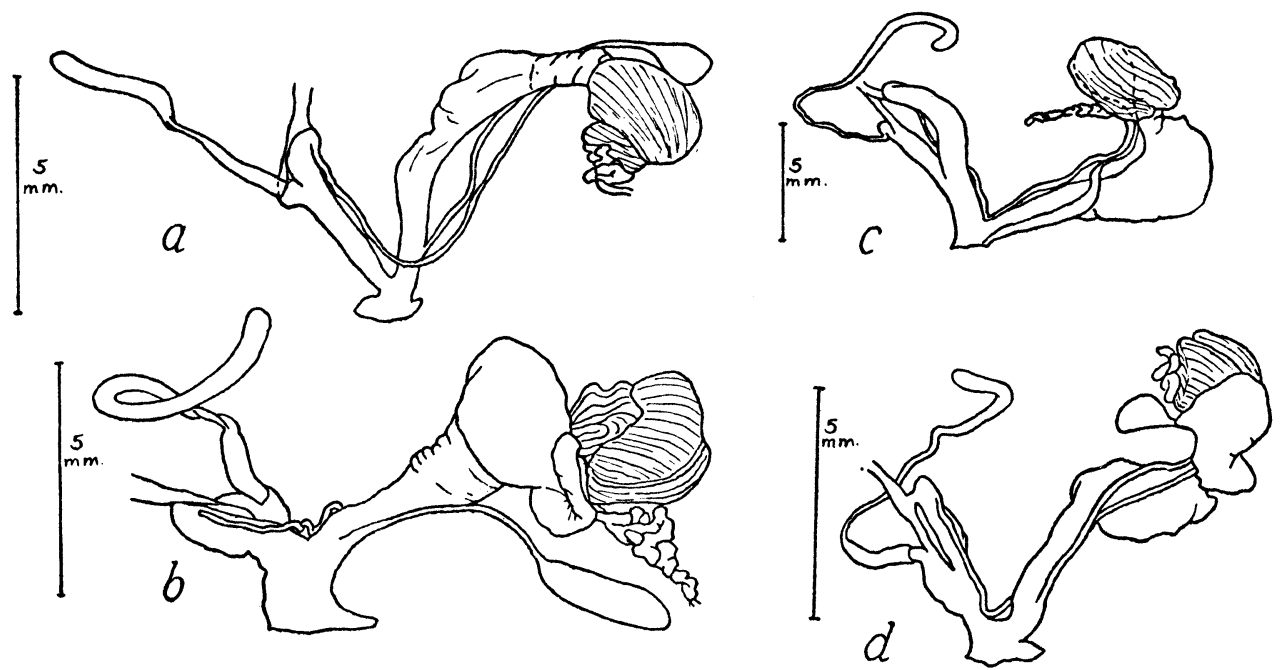

FIGURE 15.-a, Partulina maniensis (Pfeiffer), genitalia; $b$, Partulina horneri (Baldwin), genitalia; $c$, Partulina dubia (Newcomb), genitalia; $d$, Newcombia cumingi (Newcomb), genitalia.

Cooke and I have examined. Partulina redfieldii ${ }^{14}$ and tessellata, Achatinella decipens, vulpina, lorata var. pulchella, and turgida were not distinguishable from one another. Partulina proxima was similar except for a shorter first division of the appendix and a narrow kidney, which resembled that of P. rufa. P. rufa also differed in the large size of its prostate gland. $P$. virgulata differed in the longer third division of the appendix.

${ }^{13}$ Pilsbry, H. A., and Cooke, C. M., Achatinellidae: Man. Conch., vol. 22, p. xiv, 1912-1914.

${ }^{14}$ An interesting discovery was made in connection with the nervous system of $P$. redfieldii, which is, however, unrelated to the matter under discussion-the presence of a slender subcerebral commissure (fig. 16), which was found in three other Orthurethra by Hugh Watson. See The presence of a subcerebral commissure in the Urthurethra: Mal. Soc. London, Proc., vol. 15, pp. $280-283$, 1923. As it is absent in some of the higher groups of gastropods, the presence of this nerve in Achatinellidae suggests close relationship of that family with lower groups of gastropods. 


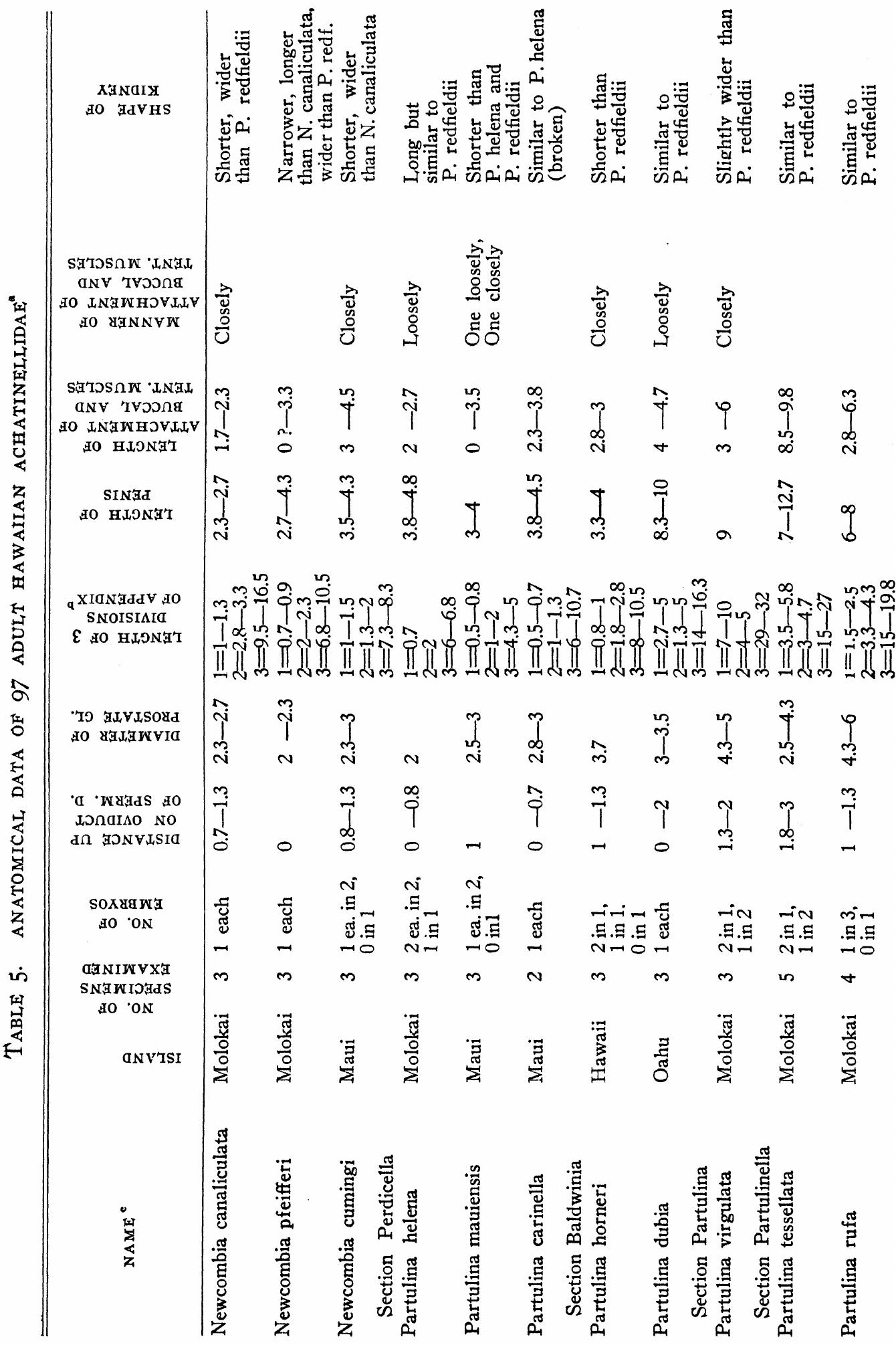


离

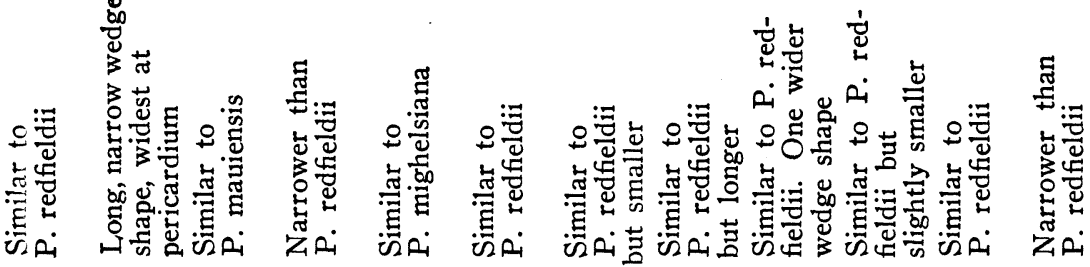
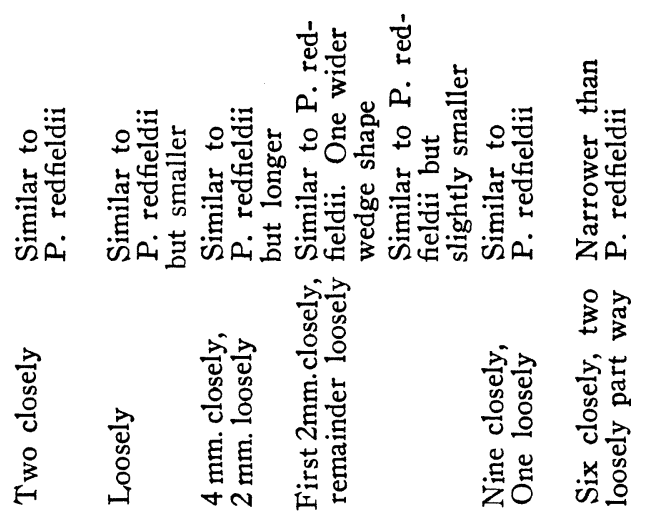

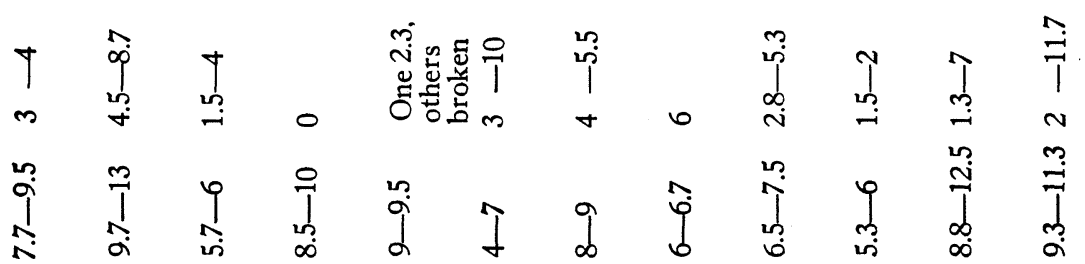
môn

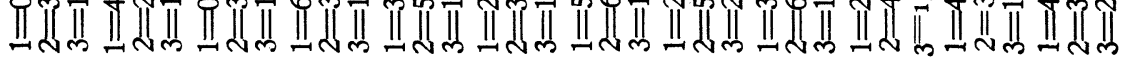

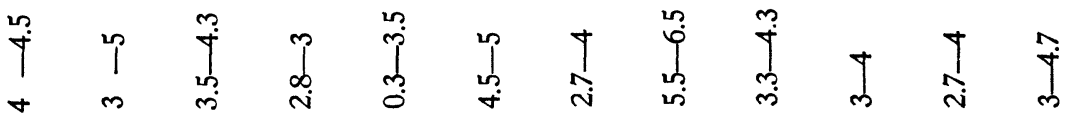

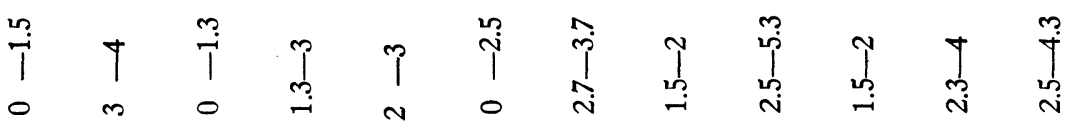

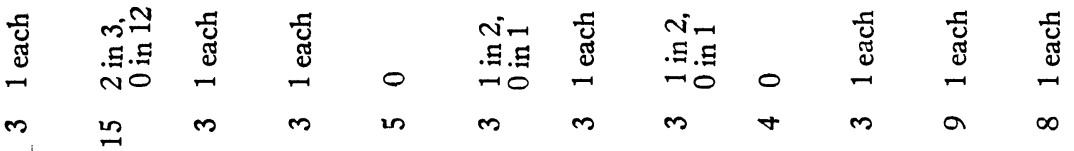

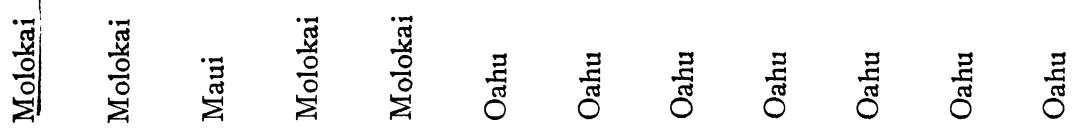

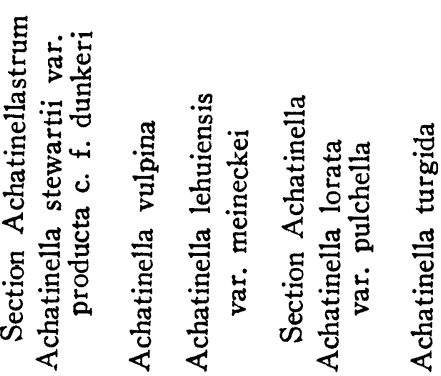

$\stackrel{0.00}{*}$

$x^{2}=$

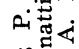

$\ddot{q}$

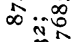

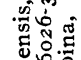

要:

a.:

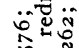

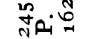

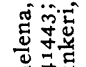

مi $\sin _{4}$

话。

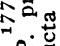

की

염

อง

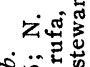

于

ग

我 से

.

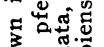

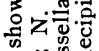

in

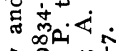

कि

荡

要过全。

ธ요

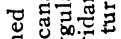

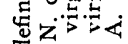

o

ง

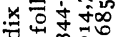

i ज 200

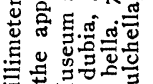

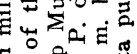

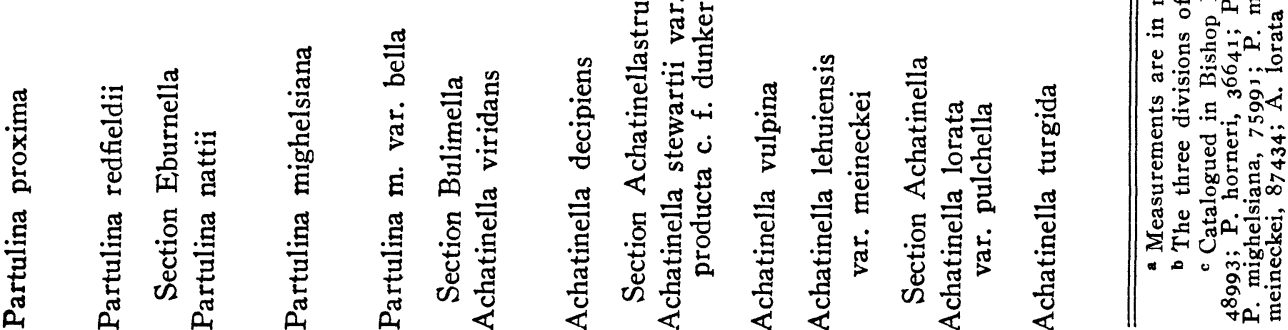


In the Manual of Conchology ${ }^{15}$ the statement is made

Borcherding tentatively suggests the view that $P$. rufa is "not a pure species, but a bastard form between $P$. tessellata Newc. on the one side, and P. proxima Pse. on the other." While this seems rather doubtful, and probably could be proved only by breeding experiments, $r u f a$ certainly unites characters of the two species. The embryo has protractive stripes as in $P$. proxima. Some very rare color forms closely resemble proxima in the later stages; but it differs from that species by the dull surface, deeply sculptured spirally; proxima being glossy, with weak spirals and very slight trace of the minute, wavy, spiral lineolation of the full Partulinas.

This, of course, deals with the shells only. Anatomically P. rufa and $P$. proxima were found to be closer to each other than to any other Partulina.

Two sections of Achatinella, represented by Achatinella viridans, lehuiensis var. meineckei, and stewartii var. producta c. f. dunkeri, were not distinguishable except in the smaller size, velvet-black mantle, and gray penis and appendix of $A$.l. meineckei.

The section Eburnella, similar in many ways to Partulina redfieldii, was not found to be uniform. For P. mighelsiana and P. mighelsiana var

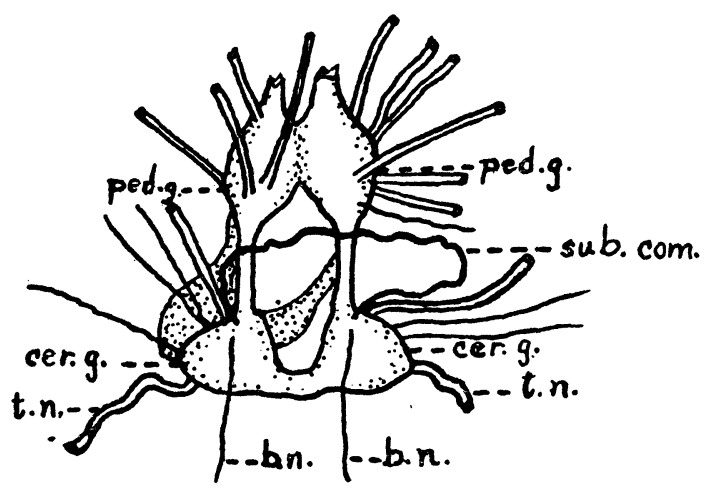

FIGURE 16.-Partulina redfieldii (Newcomb), nerve collar, b. n. = buccal nerve, cer. g. = cerebral ganglion, ped. g. = pedal ganglion, sub. com. = subcerebral commissure, t. n. = tentacular nerve. Greatly magnified.

bella though alike otherwise differed distinctly in the length of the first division of the appendix, that of the species ranging from 6 to $7 \mathrm{~mm}$., of the variety from 3 to $4 \mathrm{~mm}$. P. nattii differed even more widely. The first division of its appendix ranged from $1 / 2$ to $1 \mathrm{r} / 4 \mathrm{~mm}$., the second division and penis were shorter, and the kidney was distinctly wider than were corresponding parts of the preceding species and variety.

The section Baldwinia showed even less uniformity than Eburnella.

The three species in the section Perdicella showed fair uniformity, Partulina mauiensis differing from the other two in having a shorter third

\footnotetext{
${ }^{15}$ Pilsbry, H. A., and Cooke, C. M., Achatinellidae: Man. Conch., vol. 22, p. 30, 1912-1914.
} 
division of the appendix and a shorter kidney. In length of penis, of branch of penial retractor, and of appendix they differed from Achatinella. This is true also of the three Newcombia, which differed slightly among themselves. Perdicella and Newcombia thus seem to be the only distinct groups in the family.

\section{SUMMARY}

Though for the most part alike anatomically, according to data in Table 5 and figures 11 to 15 , a few distinct differences were found in Achatinellidae, as follows :

1. All species of Newcombia had comparatively shorter kidneys than Achatinella and Partulina.

2. Only in Partulina mighelsiana were the two free muscles, the tentacular and buccal, entirely disconnected from each other. In all other species the length and closeness of attachment varied, but not uniformly.

3. The penis varied in length, being proportionately shorter in the three Perdicella, in the three Newcombia, and also, strangely, in large Partulina horneri than in the other Achatinellidae.

4. The location of the penial retractor muscle deviated little from slightly to one side of the tip of the penis. The shortened or webbed nature of the branch of the penial retractor in Perdicella is added proof of the primitiveness of that section.

5. The length of the appendix with its three divisions bears out in a general way the relationships designated in one or more other organs.

6. In proportion to the size of the animal the prostate gland was about the same size.

7. The spermatheca was oval or elliptical in all except Partulina horneri.

8. The place of origin of the spermatheca duct on the oviduct was not constant, even in one species.

9. Divisions of the family by shell characters and anatomical characters do not agree. Judoing from the few specimens examined, some species had wide differences in measurements and in shape of some parts of their anatomy, greater proportional differences than between some of the different species. The overlapping of variations shows that anatomically Achatinella and Partulina cannot be differentiated, except in the section Perdicella and the genus Newcombia. The consistent differences of the three Perdicella from other Achatinellidae suggest that the $\operatorname{section}^{16}$ should be raised to generic rank. The decision that Newcombia should have generic value ${ }^{17}$ is confirmed.

\footnotetext{
16 op. cit., p. 15.

17 op. cit. p. 1.
} 


\section{DEVELOPMEN'T OF GENITALIA IN ACHATINEILA VIRIDANS}

While looking for differences in anatomy in different species, I noticed the disproportionate size of genitalia in comparison to the size of juvenile and adult animals, and this led to an investigation of the development of genitalia in one species. Descriptions and figures of adult genitalia of several species in the family Achatinellidae have already been published. (See page 34.)

A series of the species of land mollusk, Achatinella viridans, was collected November 26, 1926, in Waialae Iki, Oahu, Hawaii, by William H. Meinecke for Bishop Museum for use in anatomical studies. The material, consisting of sixty specimens ranging in size from newly born infants to gravid adults, was divided into six groups according to number of whorls, which ranged from 3 to $61 / 4$. In each group two or more animals were examined. (See figs. 17-22.)

\section{Group A}

The first animal examined (figure 17) was a gravid adult in the group having shells with from $53 / 4$ to $61 / 4$ whorls. All these snails were fully adult, as evidenced both by the animals and the shells, the shells having apertures with thickened lips. As was expected, each part of the genitalia was found to be fully developed. In a second specimen, the male organs were about identical in size and length; the uterus was shorter above the embryo.

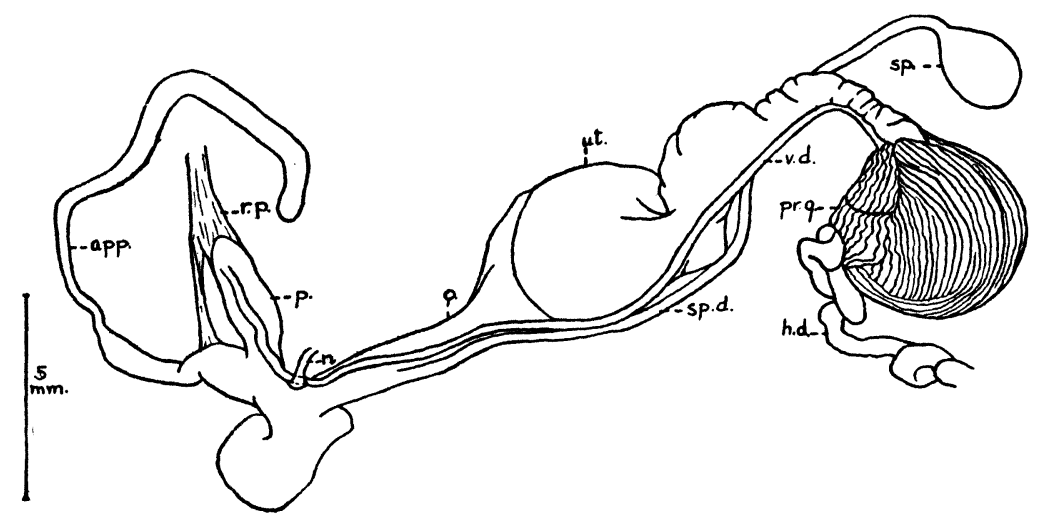

FIGURE 17.-Achatinella viridans Mighels (No. 87423), genitalia, ephebic stageapp. $=$ appendix, h. d. $=$ hermaphrodite duct, n. $=$ nerve, o. $=$ oviduct, p. $=$ penis, pr. g. = prostate gland, r. p. = retractor penis, sp. $=$ spermatheca, sp. d. $=$ spermatheca duct, ut. $=$ uterus, v. d. $=$ vas deferens. 


\section{Group B}

The second group consisted of adult snails (figure 18 ) with $53 / 4$ to $61 / 4$ whorls, the same number as in the first group. But these had no embryos, and the lip of the aperture was not thickened. Besides not being distended, the uterus was shorter, and the spermatheca seemed slightly smaller. Otherwise the organs were found to be as well developed as in Group A. As a matter of fact, in both of the two specimens examined the male organs were larger than in Group A; but whether this was due to individual variation or to some other cause was not discovered. In some other species examined, pregnancy did not affect the length of the penis.

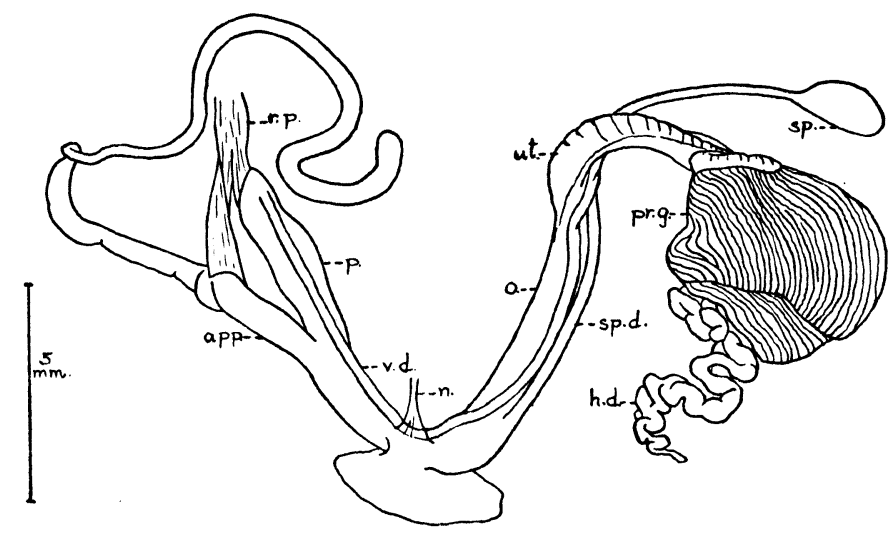

Figure 18.-Achatinella viridans Mighels (No. 87424), genitalia, ephebic stage, lettering as in figure 17.

\section{Group C}

In the third group (figure 19) a decided difference was evident, and varying stages of development were found, though the range in the number of whorls of the shells was only half of one whorl, being between $51 / 4$ and $53 / 4$, most being $51 / 2$. This seemed to be a transitional period-an extremely short one-when the snails were half way between maturity and youth, that is, in phases of the neanic stage. ${ }^{18}$. One of the specimens I examined was quite undeveloped (in the metaneanic stage), the other close to maturity (in the paraneanic stage).

The specimen in the paraneanic stage (fig. 19, a) had smaller and more slender genital organs than those in Group B. But evidently they were nearly ready to function. The uterus was as long but much narrower, and the spermatheca duct branched off from it slightly higher up. The prostate

18 op. cit., Appendix to Amastridae. Tornatellinidae, vol. 23, p. xi, 1915-1916. This and similar terms given in the following account were first used by Pilsbry and Cooke. 
gland was greatly reduced, and the spermatheca smaller. The penial retractor muscle was slender. When the dissection was made, the appendix was lying out straight, following the penial retractor muscle. Near the proximal end of the free muscles, its tip was bent down, apparently only because the cavity was not long enough to allow it to lie straight throughout its length. In all maturer specimens the appendix was found lying curled around in the region of the penis.

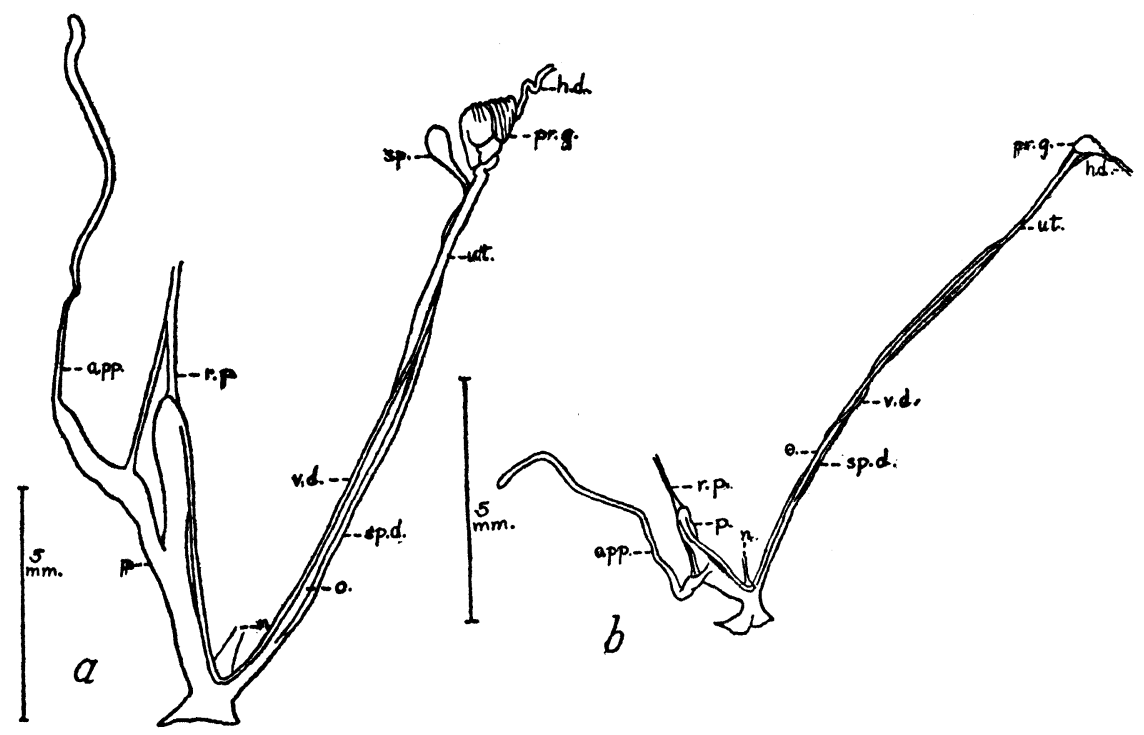

FIGURE 19.-Achatinella viridans Mighels (No. 87425), a, genitalia, paraneanic stage, lettering as in figure $17 ; b$, genitalia, metaneanic stage.

The specimen in the metaneanic stage (fig. 19, b) had no genital orifice, and none was found in still younger animals. It was present in all the preceding groups. Both male and female organs were much reduced, compared to the paraneanic stage, and were flattened, as they also were in the younger animals. I found no spermatheca. Possibly it was too minute or else homogeneous with the soft undifferentiated material of the tiny prostate gland. The spermatheca duct branched off from the uterus distinctly higher up. The penial retractor muscle was not forked. It continued from the top of the penis down the side a short way and from there was free to a point near the base of the appendix.

\section{Group D}

Examples of the ananeanic stage (fig. 20) (4 3/4 to 5 whorls) were found to have quite inconspicuous genitalia. Besides being smaller than 
Group C, another difference was found in the penial retractor muscle. The base of the appendix was webbed by it closely to the penis, from the tip of which it extended upwards in a thin thread. The spermatheca duct branched off even farther up on the uterus. The prostate gland appeared to be a short wrinkled tube.

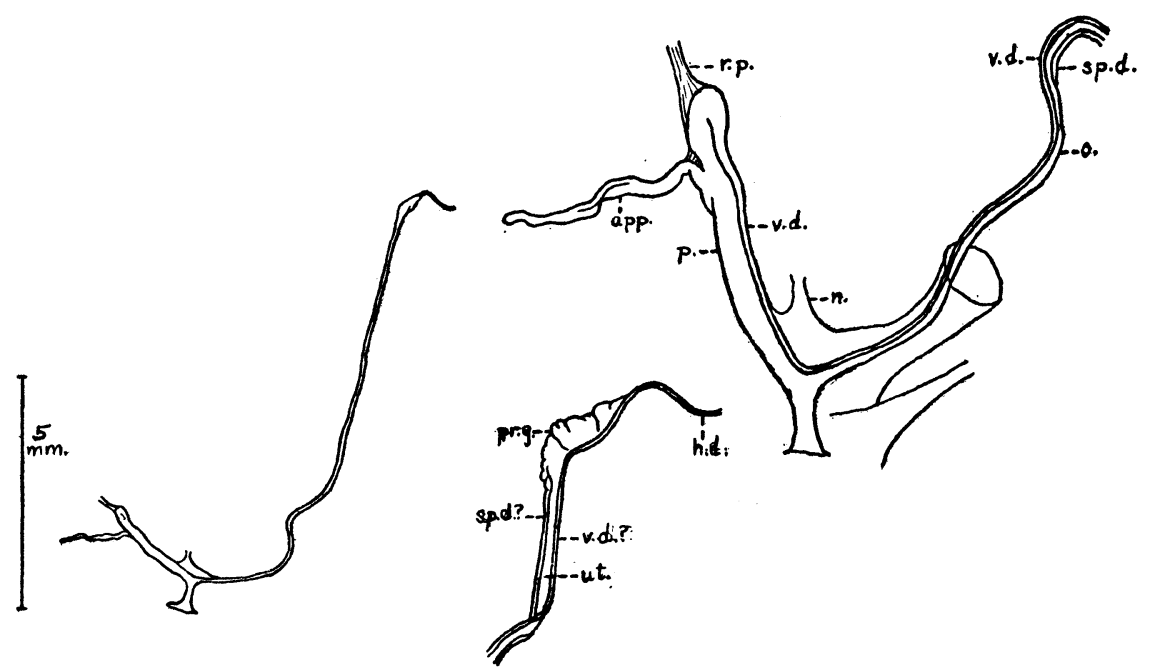

FIGURE 20.-Achatinella viridans Mighels (No. 87426), genitalia, ananeanic stage, with details, lettering as in figure 17.

\section{Group E}

In the next smaller size (figs. 21, 22, b) (4 1/2 whorls), also an ananeanic stage, the appendix and penis were shorter, and a muscle connection between them could not be distinguished. The prostate gland seemed similar to that in the preceding stage.

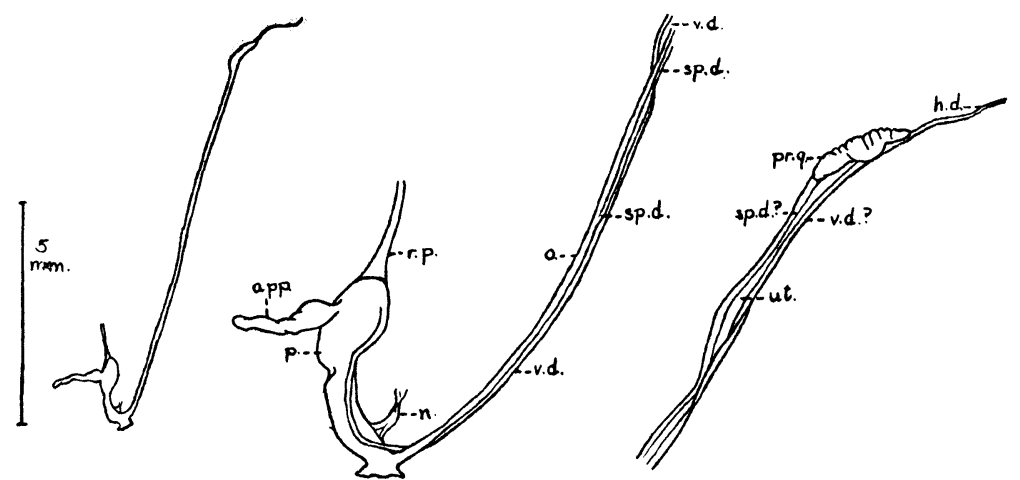

FIGURE 21.-Achatinella viridans Mighels (No. 87427), genitalia, ananeanic stage, with details, lettering as in figure 17. 


\section{Group F}

As well-developed embryos of Achatinella viridans have three whorls the next stage examined (fig. 22, $a$ ) was evidently the youngest phase of the ananeanic, the shells having 3 to $31 / 4$ whorls. The genitalia were minute and translucent, the uterus being almost transparent and also quite frail (two specimens breaking in the process of dissection at this point before a whole one could be obtained). The appendix was absent, and the penis had an enlarged tip, from which extended its retractor muscle as the finest of threads. Spermatheca duct and vas deferens had not developed, as the uterus appeared to be an unaccompanied tube. The part that would have developed into the prostate gland was not even enlarged, an angle at the tip of the uterus on one end and the narrower tube of the hermaphrodite duct on the other showing its position. It was embedded in soft clinging material, which it was necessary to remove before the outline of the tube could be seen. The uterus lay in the same position as at maturity and at its proximal end the oviduct was attached by a wide base to the wall of the animal behind the right tentacle, at the place where the genital orifice would later develop.

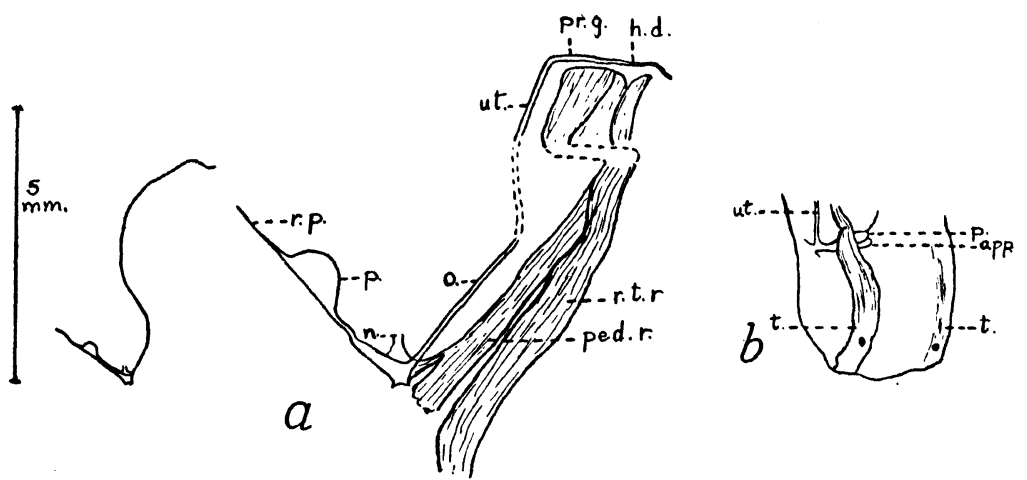

FIgURE 22.-Achatinella viridans Mighels (No. 87428): a, genitalia, ananeanic stage, with details, lettering as in figure 17 , ped. r. $=$ pedal retractor, r. t. r. $=$ right tentacular retractor; $b$, showing position of genitalia in specimen of same size as that shown in figure 21 , t. $=$ tentacle.

At this stage an important feature was a connection near the base of the penis. It led from there shortly but indirectly to the right cerebral ganglion, being a thread-like nerve in a wide filmy sheath, which may also have served to conduct arteries in this region. The connection was noted in all the other five groups, but it grew constantly looser and slighter with age and was quite insignificant in mature animals. In the same region a short connection was noted with the tip of the pedal retractor muscle, which at this growth stage stopped near the proximal end of the genitalia. 


\section{SUMMARY}

Conclusions that may be drawn in regard to the genitalia of Achatinella viridans, a representative of the Achatinellidae, are as follows:

1. They develop to greater proportions during the growth of the animal than the body of the animal.

2. They are not ready formed with the embryo but develop from simple to complex structures. In the youngest examined, the organs offered slight suggestion of their condition at maturity, the hermaphrodite duct, prostate gland, and uterus seeming to form a continuous undifferentiated tube or thread.

3. Apparently male and female organs develop equally from the youngest stage to maturity and are ready to function at the same time. So far as observed they are present during the entire life of the animal. 


$$
\text { . }
$$


. 


\section{.}




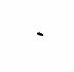


• 


\section{BOUND}

\section{AUG2 81944 \\ UNIV. OF MHCH.
LIBRARY}

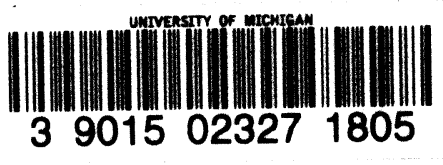

Filmed by Preservation

1996 
